\title{
A sulfate conundrum: Dissolved sulfates of deep-saline brines and carbonate-associated sulfates
}

Dana M. Labotka *, Samuel V. Panno, Randall A. Locke

Illinois State Geological Survey, Prairie Research Institute,

University of Illinois, Champaign, IL, United States

* Corresponding author. Tel.: +1 (217) 244 7972; fax: +1 (217) 3332830.

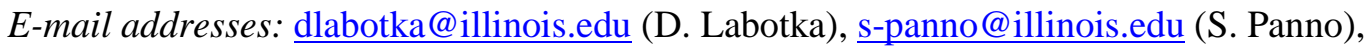

rlocke@illinois.edu $($ R. Locke).

(C) 2016. This manuscript version is made available under the Elsevier user license http://www.elsevier.com/open-access/userlicense/1.0/ 


\begin{abstract}
Sulfates in deeply circulating brines and carbonate-associated sulfates (CAS) within sedimentary units of the Cambrian strata in the Illinois Basin record a complex history. Dissolved sulfate within the Mt. Simon Sandstone brines exhibits average $\delta^{34} \mathrm{~S}_{\mathrm{SO} 4}$ values of $35.4 \%$ and $\delta^{18} \mathrm{O}_{\mathrm{SO} 4}$ values of $14.6 \%$ and appears to be related to Cambrian seawater sulfate, either original seawater or sourced from evaporite deposits such as those in the Michigan Basin. Theoretical and empirical relationships based on stable oxygen isotope fractionation suggest that sulfate within the lower depths of the Mt. Simon brines has experienced a long period of isolation, possibly several tens of millions of years. Comparison with brines from other stratigraphic units shows the Mt. Simon brines are geochemically unique. Dissolved sulfate from brines within the Ironton-Galesville Sandstone averages $22.7 \%$ for $\delta^{34} \mathrm{~S}_{\mathrm{SO} 4}$ values and $13.0 \%$ o for $\delta^{18} \mathrm{O}_{\mathrm{SO} 4}$ values. The Ironton-Galesville brine has mixed with younger groundwater, possibly of Ordovician to Devonian age and younger. The Eau Claire Formation lies between the Mt. Simon and Ironton-Galesville Sandstones. The carbonate units of the Eau Claire and stratigraphically equivalent Bonneterre Formation contain CAS that appears isotopically related to the Late Pennsylvanian-Early Permian Mississippi Valley-type ore pulses that deposited large sulfide minerals in the Viburnum Trend/Old Lead Belt ore districts. The $\delta^{34} \mathrm{~S}_{\mathrm{CAS}}$ values range from $21.3 \%$ to $9.3 \%$, and $\delta^{18} \mathrm{O}_{\mathrm{CAS}}$ values range from $+1.4 \%$ to $-2.6 \%$ and show a strong covariance $\left(\mathrm{R}^{2}=0.94\right)$. The largely wholesale replacement of Cambrian seawater sulfate signatures in these dolomites does not appear to have affected the sulfate signatures in the Mt. Simon brines even though these sulfide deposits are found in the stratigraphically equivalent Lamotte Sandstone to the southwest. On the basis of this and previous studies, greater fluid densities of the Mt. Simon brines may have prevented the less dense Mississippi Valley-type fluids from interacting with these deeply circulating brines. Progressive in situ quartz cementation that occurred in the Mt. Simon Sandstone contemporaneous to the ore pulses may also have precluded fluid migration. The Mt. Simon brines appear to be a mixture of evaporated connate Cambrian seawater, recirculating deep-seated crystalline basement brines, and meteoric water.
\end{abstract}


Keywords:

Cambrian brines; Illinois Basin; Sulfate isotope geochemistry; Carbonate-associated sulfate; Mississippi Valley-type ore fluids 


\section{INTRODUCTION}

The evolution of the Cambrian seas witnessed a distinctive time in Earth history. Seawater sulfate concentrations were low, 3.5 times less concentrated that modern seawater (Brennen et al., 2004).

Nevertheless, the estimated $\delta^{34} \mathrm{~S}$ values of Cambrian seawater sulfate are some of the most enriched in Phanerozoic history, having general values of $+30 \%$ and extreme values reported as $+50 \%$ (e.g., Claypool et al., 1980; Kampschulte and Strauss, 2004; Schröder et al., 2004; Hough et al., 2006; Gill et al., 2007). Episodes of increased pyrite burial, widespread ocean anoxia, and influences of bacterial sulfate reduction are thought to have played the main roles in seawater sulfur evolution through the Cambrian (e.g., Algeo et al., 2015; Hough et al, 2006). Phanerozoic seawater sulfate isotope values, $\delta^{34}$ S and $\delta^{18} \mathrm{O}$, have been estimated from evaporite deposits and carbonate-associated sulfates (CAS) with significant success (e.g., Claypool et al., 1980; Kampschulte and Strauss, 2004). In this study, we sought to determine whether the complicated history of Cambrian seawater sulfate is preserved within and could be unraveled from deep-seated Cambrian brines.

The Mt. Simon Sandstone is a unique Cambrian environment that hosts deep-saline brines that are geochemically distinct from surrounding intrabasinal brines and extrabasinal brines. Suspected sources for these Cambrian-hosted brines are original Cambrian seawater, meteoric water, and deepseated circulating groundwater (Panno et al., 2013; Labotka et al, 2015). Understanding the geochemical evolution of brines provides essential insights into numerous geological processes, such as water-rock interaction and groundwater chemistry and movement. More recently, deep-saline brines have been investigated for their suitability as storage reservoirs for carbon sequestration (e.g., Locke et al., 2013). Isotopes of dissolved sulfate offer direct, critical information about the formational and evolutionary history of fossil brines, including their origin, seawater components, mixing or dilution potential, sulfide oxidation and sulfate reduction, and microbial influence (e.g., Kampschulte and Strauss, 2004; Gill et al., 2011; Rennie and Turchyn, 2014). 
This investigation utilizes the isotopes of sulfur and oxygen in dissolved sulfate from deep-seated brines of the Cambrian-aged Mt. Simon and Ironton-Galesville Sandstones in addition to CAS from the Cambrian-aged Eau Claire Formation and stratigraphically equivalent Bonneterre Formation from the midcontinent of North America. No sulfate deposits are documented in the Mt. Simon Sandstone. The Eau Claire Formation separates the younger Ironton-Galesville Sandstone from the underlying Mt. Simon Sandstone. The $\delta^{34} \mathrm{~S}$ and $\delta^{18} \mathrm{O}$ values of CAS from the carbonate units and evaporite deposits of the Eau Claire and Bonneterre Formations may represent a sulfate source for the Mt. Simon and IrontonGalesville brines. During the Late Pennsylvanian and Early Permian, pulses of Mississippi Valley-type (MVT) ore fluids were emplaced throughout Middle Cambrian and Lower Ordovician carbonate rocks in North America (Gregg and Shelton, 2012). Evidence of these MVT ore fluids have been observed in the Lamotte Sandstone of Missouri, which is stratigraphically equivalent to the Mt. Simon Sandstone. These ore sulfide deposits exhibit a range of $\delta^{34} \mathrm{~S}$ values distinct from Cambrian seawater sulfate values. Analysis of the sulfate isotopes from the Mt. Simon and Ironton-Galesville brines and the CAS of the Cambrian carbonate units of the Eau Claire and Bonneterre Formations will help determine the potential sources of sulfate in these Cambrian sandstone-hosted brines. This investigation explores the possible origins and preservation potential of dissolved sulfate, CAS, and evaporites in the Cambrian environment and the implications for environmental reconstruction during the Cambrian.

\section{GEOLOGICAL ENVIRONMENT}

\subsection{General overview}

Initial groundwater sampling for the deep-seated brines began with the Illinois Basin-Decatur Project (IBDP). The IBDP is part of a large carbon sequestration research effort conducted by the Illinois State Geological Survey as the lead agency with the Midwest Geological Sequestration Consortium. Efforts are funded through the U.S. Department of Energy Carbon Storage Program. A deep borehole (VW1) was drilled in 2009 in Decatur, Illinois (3950.1' N; 8951.5' W; Fig. 1), to a depth of 2,155 m, penetrating the Mt. Simon Sandstone in the Illinois Basin, which is $\sim 457 \mathrm{~m}$ thick at this location. The 
thickest section of the Mt. Simon in the Illinois Basin lies northwest of the IBDP site and is $\sim 792 \mathrm{~m}$ in thickness.

The Mt. Simon Sandstone, Eau Claire Formation, Bonneterre Formation, and Ironton-Galesville Sandstone are all Cambrian strata that are part of the Sauk Sequence. This sedimentary sequence in Laurentia covers Precambrian to Lower Ordovician strata deposited $~ 543$ to 490 million years ago (Kolata, 2010; Figs. 1 and 2). Sauk II, Middle to early Late Cambrian, consists of the Mt. Simon Sandstone and overlying Eau Claire Formation (to the north) and stratigraphically equilivalent Lamotte Sandstone and overlying Bonneterre Formation (to the south). The Sauk III Sequence begins with the Ironton-Galesville Sandstone, which overlies the Bonneterre and Eau Claire Formations. The Sauk II/III transition occurs at the top of the Eau Claire and Bonneterre Formations as an erosional disconformity that likely occurred during a short but continent-wide lowering in global sea level (Palmer, 1981). The transition between the Eau Claire Formation (Sauk II) and Ironton-Galesville Sandstone (Sauk III) is marked by renewed sea transgression accompanied by the deposition of quartz sandstones and siliciclastics followed by carbonate deposition. The Precambrian basement rock exhibits irregular relief and topographic highs that extend above the sedimentary deposition of the Eau Claire and Bonneterre Formations, forming erosionally resistent islands in shallow epiric seas (Gregg, 1985).

\subsection{Mt. Simon Sandstone}

The Mt. Simon Sandstone is a Cambrian sedimentary unit composed of quartzose to arkosic sandstones with few interbedded shales and is seemingly lacking in evaporites. The Mt. Simon lies disconformably over the Argenta Formation, which is a sandstone/conglomerate deposit that unconformably overlies Precambrian igneous basement (Freiburg et al., 2014). During the early Paleozoic, rifting events created the Illinois Basin in which the Mt. Simon Sandstone was deposited (Ervin and McGinnis, 1975; Kolata and Nelson, 2010). Paleogeographically, the Mt. Simon was situated just south of the equator as part of the paleocontinent Laurentia (Scotese and McKerrow, 1990; Fig. 1).

The Mt. Simon is composed of eolian, fluvio-deltaic, and shallow marine siliciclastic sediments (Freiburg et al., 2014) and is stratigraphically equivalent to the Lamotte Sandstone in Missouri (Workman and Bell, 
1948). Sediment sources for the Mt. Simon are reported to originate from the Canadian Shield and St. Francois Mountains (Ojakangas, 1963; Houseknecht and Ethridge, 1978). Hyodo et al. (2014) reiterated this conclusion and suggested that the detrital quartz at the study site in Decatur, Illinois, was predominantly igneous in origin based on the $\delta^{18} \mathrm{O}$ values of the quartz grains.

The Mt. Simon is divided into three general depositional units based on mineralogy and cementation: lower, middle, and upper. Gamma ray and neutron porosity logs were used to determine permeability and porosity. In the sample core, VW1, from Decatur, Illinois, the Lower Mt. Simon (1,951 to 2,134 $\mathrm{m}$ in depth) exhibits relatively high porosity (up to $26.4 \%$ ) and permeability and is largely composed of fluvial braided river deposits. The Middle Mt. Simon (1,795 to 1,951 $\mathrm{m}$ in depth) is a lowporosity quartz-cemented sandstone unit characterized by eolian and fluvial deposits. The Upper Mt. Simon (1,684 to $1,975 \mathrm{~m}$ in depth) consists of intertidal sandstones and interbedded shales with moderate porosity ( 15\%; Freiburg et al., 2014). The Mt. Simon and Lamotte Sandstones are conformably overlain by the Eau Claire and Bonneterre Formations, respectively (Kolata, 2010). Detailed petrographic, diagenetic, and depositional descriptions of the Mt. Simon environment can be found in Freiburg et al. (2014).

\subsection{Eau Claire and Bonneterre Formations}

The Eau Claire and Bonneterre are contemporaneous formations in the Upper Cambrian. The Eau Claire Formation at VW1 is largely a siliciclastic unit composed of tidally deposited shales, mudstones, siltstones, and sandstones in the lower section and dolomite and siltstone in the upper section (Buschbach, 1975; Treworgy et al., 1997; Neufelder et al., 2012). The Eau Claire Formation is the primary caprock unit for the IBDP Regional Carbon Sequestration Partnership project (Locke et al., 2013; Freiburg et al., 2014). The formation is $152 \mathrm{~m}$ in thickness at depths of 1,529 to $1,681 \mathrm{~m}$, where it conformably overlies the Mt. Simon Sandstone. The Eau Claire becomes more carbonaceous progressing paleographically southward from the inner detrital belt into the carbonate belt toward the Bonneterre Formation (Fig. 1). In southwestern Illinois, the Eau Claire is predominantly dolomite and limestone. The depocenter for the Eau Claire and Bonneterre lies in western Kentucky (Kolata, 2010). 
The Eau Claire becomes the Bonneterre Formation in Missouri (Runkel et al., 2012). The Bonneterre Formation consists of glauconite-bearing shallow-marine carbonates (Saltzman et al., 2004; Runkel et al., 2012). In southeast Missouri, the Bonneterre Formation is predominatly a carbonate sequence characterized by algal bioherms and associated shelf carbonates deposited around the topographic highs of the Precambrian St. Francis Mountains (Gregg, 1988).

In western Illinois, the Eau Claire/Bonneterre Formation is 60-90 m thick (Buschbach, 1975) and thickens to $\sim 370 \mathrm{~m}$ in southernmost Illinois (Sargent, 1991). Trilobite assemblages constrain the age of the Eau Claire and Bonneterre Formations to Dresbachian Stage, 501 to 497 million years ago (Cohen et al., 2013; Fig. 2). The Eau Claire contains the trilobite assemblage of Cedaria, Crepicephalus, Aphelaspis, and Dunbergia Zones (McKay, 1988), and the Bonneterre Formation is reported to have Crepicephalus and Aphelaspis Zones (Thompson, 1995).

Widespread dolomitization has affected the Bonneterre Formation and extended into the Illinois Basin in parts of the Eau Claire Formation (Buschbach, 1975; Rogers and Davis, 1977; Sargent, 1991). This pervasive dolomitization occurred early in diagenesis. Later, a neomorphic recrystallization and cementation occurred that was associated with fluids from the orogenic pulses that left the widespread lead-zinc-copper sulfide mineral districts of the MVT deposits (Goldhaber, 2004; Gregg and Shelton, 2012). The MVT fluids are suspected to originate from basinal brines composed of mostly evaporated seawater or water with dissolved halite and constituents from interactions with sedimentary rocks, basement rocks, or both (Bethke, 1986). Temperatures of the migrating MVT fluids are estimated to have been between 75 and $150{ }^{\circ} \mathrm{C}$ (Basuki and Spooner, 2002) and later refined to 100 and $150{ }^{\circ} \mathrm{C}$ (Goldhaber, 2004). The general timing of MVT fluids affecting the midcontinental region is associated with the Alleghanian-Ouachita orogeny during the Late Pennsylvanian-Early Permian (Gregg and Shelton, 2012). From petrographic observations, these Cambrian-age carbonates exhibit a coarse crystalline texture with numerous small cavities. These cavities are generally lined with dolomite-rhomb crystals. The dolomite is dark brown to light gray in color. The carbonates of the Eau Claire and Bonneterre Formations can be stratigraphically divided into depositional environments with the top one-third of the 
section as carbonate sands and the remaining two-thirds constituting the fore reef, reef, and back reef environment (Rogers and Davis, 1977). The carbonate sands exhibit a dark gray-brown mottled texture of coarse crystalline carbonate. The lower two-thirds of the carbonate section exhibit a light gray mottled dolomite texture. Pyrite is sparsely disseminated throughout the Eau Claire and Bonneterre Formation cores. Fenestral porosity and dark gray algal laminations are common.

\subsection{Ironton-Galesville Sandstone}

A global sea level regression occurred during the Late Cambrian, resulting in significant erosion of the Eau Claire and Bonneterre Formations and subsequent deposition of mature quartz sandstones of the Ironton-Galesville (Palmer, 1981; Saltzman et al., 2004). The Ironton-Galesville Sandstone contains Elvinia trilobites. The Elvinia Zone marks the beginning of the Franconian Stage and Sauk III Sequence in Illinois. The Ironton-Galesville Sandstone is present in central Illinois (Freiburg et al., 2014) but is largely absent in southern Illinois (Shaw and Sargent, 1989) and southern Missouri (Thompson, 2001). In eastern Missouri, the lower section of the Davis Formation is equivalent to the Ironton-Galesville Sandstone (Droste and Patton, 1985). Widespread carbonate deposition across the North American craton was followed by the Franconia Formation in the north and stratigraphically equivalent Derby-Doerun Formation toward the south. In northern Illinois, the Franconia Formation is glauconitic and dolomitic sandstone, which becomes the relatively pure dolomite facies of the Derby-Doerun Formation progressing to the south (Kolata, 2010; Fig. 2).

\subsection{Hydrogeology of the Cambrian-Ordovician aquifer}

In some investigations, the aquifers of the Mt. Simon Sandstone, the Ironton-Galesville Sandstone, the Glenwood-St. Peter Sandstone, and the Galena-Platteville Dolomite are often referred to as the Cambrian-Ordovician aquifer and are treated as a single hydrogeologic unit (Siegel and Mandle, 1984; Siegel, 1989). In the northern one-third of Illinois, these formations are used extensively for potable groundwater from municipal and industrial wells that might intersect multiple formations with a single well (Larson and Herzog, 2004). The Mt. Simon Sandstone is protected by the Eau Claire Formation, which acts as a confining unit between the Mt. Simon Sandstone and the overlying Ironton-Galesville 
Sandstone. The Mt. Simon Sandstone is used as a source of drinking water only in the extreme northern part of Illinois. Because of the elevated salinity and the greater depth of the Mt. Simon within the Illinois Basin, it is not a potable water source farther south. Although the Mt. Simon contains cemented but friable sandstone in the northern part of the basin, and thus has a greater hydraulic conductivity, the hydraulic conductivity of the Mt. Simon Sandstone in general is relatively low. The Ironton-Galesville Sandstone, composed of well-sorted, fine-grained sandstone, is a productive aquifer in the northern onethird of Illinois, where its total dissolved solids (TDS) are sufficiently low for potability; farther south within the basin, groundwater within the Ironton-Galesville Sandstone is too saline for drinking water (Larson and Herzog, 2004).

At the study site in central Illinois, the Cambrian-aged Mt. Simon and Ironton-Galesville Sandstones host deep-saline brines that are geochemically distinct (Table 1). The sandstone units do not act as part of one hydrologic unit. The Eau Claire Formation is the only stratigraphic formation that separates these two sandstone units. The Ironton-Galesville brine exhibits a salinity of $\sim 66 \mathrm{~g} / \mathrm{L}$ of TDS and has a distinct meteoric water component to the brine, with water isotope values of $-7.2 \%$ for $\delta^{18} \mathrm{O}$ and $-54 \%$ for $\delta \mathrm{D}$. The Ironton-Galesville brine isotope values are similar to shallow groundwater values for the area, $-7 \%$ for $\delta^{18} \mathrm{O}$ and $-48 \%$ for $\delta \mathrm{D}(n=55$; Labotka et al., 2015). The Ironton-Galesville Sandstone appears more hydrologically connected with other brines in the Illinois Basin, such as some brines in Ordovician strata and possibly glacial recharge from the northern edge of the basin (Siegel and Mandle, 1984; Labotka et al., 2015). In contrast, the Mt. Simon brines exhibit a much greater density of $\sim 195 \mathrm{~g} / \mathrm{L}$ of TDS and have isotopically more enriched water isotope values, $-3.6 \%$ for $\delta^{18} \mathrm{O}$ and $-26 \%$ o for $\delta \mathrm{D}$. The $\mathrm{Cl} / \mathrm{Br}$ ratios of the Mt. Simon and Ironton-Galesville brines are lower than those of other sedimentary brines within the Illinois Basin and appear stratified, indicating multiple origins of saline groundwater and brines (Panno et al., 2013).

\section{MATERIALS AND METHODS}

\subsection{Sampling strategy}




\subsubsection{Brine samples}

The VW1 well in Decatur, Illinois, was perforated with 11 vertically isolated zones, 9 in the Mt. Simon Sandstone and 2 in the Ironton-Galesville Sandstone. Brine samples were taken from each of the vertically isolated zones in the Mt. Simon Sandstone (zones 2-9) and Ironton-Galesville Sandstone (zones 10-11) at a depth of 1,500 to 2,130 m below land surface. Zone 1 was in the rhyolitic basement rock, where brine samples were not taken. Samples were collected according to standard swabbing techniques outlined in Locke et al. (2013) and Panno et al. (2013), which describe individual zone isolation procedures. At each zone, fluid was purged (>287,700 L) until measured environmental parameters (i.e., $\mathrm{pH}$ and density) stabilized at the wellhead to ensure representative samples (Table 1). After swab sampling was completed, the temperature was measured using instruments deployed in each VW1 zone. Samples were stored in polyethylene bottles and kept in cold storage $\left(4^{\circ} \mathrm{C}\right)$ until analysis. Locke et al. (2013) describe the well construction and sampling procedures in detail.

Zones 2-7 were located in the Lower Mt. Simon. Zone 7 was located near the base of the Middle Mt. Simon at an abrupt transition between the Lower and Upper Mt. Simon and is discussed as part of the Lower Mt. Simon. Zones 8-9 were in the Upper Mt. Simon. The Lower Mt. Simon brine samples were taken from a depth of approximately 2,116 to 1,944 m. The Upper Mt. Simon brine samples were taken from a depth of approximately 1,770 to 1,714 m below land surface. The overlying Ironton-Galesville Formation was divided into two sampling zones (zones 10-11) at depths of 1,515 and 1,490 m, respectively, below land surface (Table 1).

\subsubsection{Whole-rock samples from the Cambrian formations for CAS}

Core samples from the Cambrian carbonate facies of the Eau Claire Formation in Illinois and the Bonneterre Formation in Missouri were investigated. In 1959, core samples (2.5 inches in diameter) that penetrated the entire Eau Claire Formation were drilled by the Mississippi River Company in Madison County, Illinois, and are archived at the Illinois State Geological Survey (Shaw and Sargent, 1989). Samples were collected from two separate cores at two different but nearby drill sites: C-8949 $\left(38^{\circ} 40.68^{\prime}\right.$ 
$\left.\mathrm{N} ; 89^{\circ} 45.19^{\prime} \mathrm{W}\right)$ and C-8948 (38³9.81'N; $89^{\circ} 46.30^{\prime} \mathrm{W}$; Fig. 1). The thickness of the Eau Claire Formation at C-8949, $91 \mathrm{~m}$, was logged at depths of 1,389 to 1,480 m below land surface. Note that the Mt. Simon Sandstone is absent in the C-8949 core and the Eau Claire Formation unconformably overlies the Precambrian bedrock. Three samples from the carbonate facies of the Eau Claire at depths of 1,417, 1,446, and 1,448 m were collected from core C-8949. In core C-8948, the Eau Claire Formation was logged as occurring at depths of 1,432 to $1,568 \mathrm{~m}$ below the surface, with a thickness of $136 \mathrm{~m}$. In the C8948 core, the Mt. Simon Sandstone was 18 m thick. One sample was collected from the carbonate facies of the Eau Claire from core C-8948 at a depth of 1,433 m. These two sites, C-8949 and C-8948, are 2 $\mathrm{km}$ apart on the surface but exhibit notable differences in formation depth and thickness. Chipped carbonate rock samples of the Bonneterre Formation used in this study were collected from the entrance shaft wall of the Buick Mine $\left(37^{\circ} 39.0^{\prime} \mathrm{N} ; 9^{\circ} 9.0^{\prime} \mathrm{W}\right.$ ) by S.V. Panno (see Panno et al., 1988) in Iron County, Missouri, at an estimated depth of $335 \mathrm{~m}$ below the surface. The Buick Mine is $~ 165$ to $167 \mathrm{~km}$ west of the two Eau Claire Formation sites in Madison County, Illinois (Fig. 1).

\subsubsection{Anhydrite samples from the Eau Claire Formation}

Three anhydrite samples were microdrilled from drill core spanning the Eau Claire Formation from two different drill sites. At VW1, 28 $\mathrm{m}$ of the Eau Claire formation (152 $\mathrm{m}$ thick) was recovered from depths of 1,653 to $1,681 \mathrm{~m}$. At the base of the core, 1,681 m, the Eau Claire conformably overlies the Mt. Simon Sandstone (Freiburg et al., 2014). Two anhydrite samples were taken, each from a depth of 1,681 $\mathrm{m}$ (Table 2). At VW1, the lower section of the Eau Claire Formation is predominantly tidal shale, silty mudstone, muddy siltstone, clean siltstone, and sandstone (Neufelder et al., 2012). The upper section of the Eau Claire consists largely of dolomite and siltstone (Buschbach, 1975; Treworgy et al., 1997).

A third anhydrite sample was taken from Marion County, Illinois, $\left(38^{\circ} 36.0^{\prime} \mathrm{N} ; 8^{\circ} 07.8^{\prime} \mathrm{W}\right.$; hole 52358\#2; Stevenson et al., 1975). In 1966, the Texaco Oil Co. drilled a hole 2,807 m deep in the Fairfield Basin, and the Eau Claire was logged at 2,324 to 2,576 $\mathrm{m}$ in depth. This anhydrite sample was taken from a depth of 2,366 m (Table 2). The Eau Claire Formation in southern Illinois is predominantly 
carbonate, with siltstone, shale, and sandstone. In the Fairfield Basin, the Eau Claire is 180 to $305 \mathrm{~m}$ thick. All core is stored at the Natural Resources Studies Annex at the University of Illinois at UrbanaChampaign.

\subsection{Analytical methodology}

Results and methodology of the dissolved ion analysis and bulk chemistry and stable isotopes of $\delta \mathrm{D}$ and $\delta^{18} \mathrm{O}$ of the Mt. Simon and Ironton-Galesville brines were previously published in Labotka et al. (2015). The data are replicated in Table 1 for isotope activity calculations for comparison with sulfate isotope values.

\subsubsection{Brine and dissolved $\mathrm{SO}_{4}{ }^{2-}$ stable isotope composition analysis}

The oxygen and hydrogen isotope composition of brines $\left(\delta^{18} \mathrm{O}_{\text {brine }}\right.$ and $\left.\delta \mathrm{D}_{\text {brine }}\right)$ and the sulfur and oxygen isotope composition of dissolved sulfate $\left(\delta^{34} \mathrm{~S}_{\mathrm{SO} 4}\right.$ and $\left.\delta^{18} \mathrm{O}_{\mathrm{SO} 4}\right)$ were analyzed for the Mt. Simon and Ironton Galesville Sandstone brines. The $\delta^{34} \mathrm{~S}_{\mathrm{SO} 4}$ and $\delta^{18} \mathrm{O}_{\mathrm{SO} 4}$ are new data, whereas the $\delta^{18} \mathrm{O}_{\text {brine }}$ and $\delta \mathrm{D}_{\text {brine }}$ values were previously published in Labotka et al. (2015). Isotopes are reported in delta notation in per mille $(\%)$ :

$\delta=\left[\left(R_{\text {sample }} / R_{\text {standard }}\right)-1\right] \times 10^{3}$,

where $R_{\text {sample }}$ is the molar ratio of the rare to abundant isotope of the unknown sample and $R_{\text {standard }}$ is the molar ratio of the rare to abundant isotope of a known standard.

Dissolved sulfates were prepared for isotope analysis of $\delta^{34} \mathrm{~S}_{\mathrm{SO} 4}$ and $\delta^{18} \mathrm{O}_{\mathrm{SO} 4}$ values at the Illinois State Geological Survey. The brine samples were treated twice with $\mathrm{HCl}$ to a solution from $\mathrm{pH}$ of 3 or 4 with $18 \mathrm{M} \Omega \cdot \mathrm{cm}$ water rinse between acidifications to remove any traces of carbonates. A supersaturated solution of $\mathrm{BaCl}_{2}$ was added to precipitate $\mathrm{BaSO}_{4}$. The $\mathrm{BaSO}_{4}$ precipitates were collected via vacuum filtration and dried. No fractionation occurred between the precipitation/dissolution of $\mathrm{BaSO}_{4}$ and dissolved sulfate at low temperatures $\left(110-350{ }^{\circ} \mathrm{C}\right.$; Kusakabe and Robinson, 1977). Isotope analysis was conducted at the Stable Isotope Laboratory at the University of Tennessee, Knoxville. The $\delta^{34} \mathrm{~S}_{\mathrm{SO} 4}$ and $\delta^{18} \mathrm{O}_{\mathrm{SO} 4}$ values of the prepared barium sulfate were measured using a dual-inlet isotope ratio mass 
spectrometer (Thermo Finnigan Delta Plus IRMS). Samples were compared with internal and international standards for precision and accuracy. For sulfur analysis, the $\mathrm{BaSO}_{4}$ was packed in tin capsules with a $\mathrm{V}_{2} \mathrm{O}_{5}-\mathrm{SiO}_{2}$ additive for conversion of the sulfate to $\mathrm{SO}_{2}$ (g) following the methods of Yanagisawa and Sakai (1983) and Ueda and Krouse (1986). The tin capsules were combusted at high temperature in a $\mathrm{He}$ atmosphere in the presence of excess oxygen by using a Costech ECS4010 Elemental Analyzer gas chromatograph. The gas chromatograph directed the resultant $\mathrm{SO}_{2(\mathrm{~g})}$ into the continuousflow Thermo Finnigan Delta Plus IRMS, where the isotopes were separated and measured. The $\delta^{34} \mathrm{~S}$ values are reported relative to the Vienna Canyon Diablo Troilite (V-CDT) standard. The standard error for $\delta^{34} \mathrm{~S}$ values of isotope standard NBS-127 was $0.07 \%$ o $(\mathrm{n}=2)$ and that for IAEA-SO- 6 was $0.04 \%$ ( $\mathrm{n}=$ 2). Individual samples were run in duplicate, with a standard error of $0.10 \%$ for $\delta^{34} S_{\text {SO4 }}$ values (Table 1). For oxygen isotope analysis, the $\mathrm{BaSO}_{4}$ precipitates were loaded into silver caps, which underwent pyrolysis in a graphite furnace in a Thermal Conversion Elemental Analyzer at $1,450{ }^{\circ} \mathrm{C}$ and were then transferred by continuous He flow to the Thermo Finnigan Delta Plus IRMS for isotope analysis. One standard deviation for $\delta^{18} \mathrm{O}$ values reported relative to $\mathrm{V}-\mathrm{SMOW}$ of isotope standard IAEA-SO-6 was 0.04\%o $(n=3)$, and an in-house standard was $0.05 \%$ ( $(n=3)$. Individual samples were run in duplicate, with a standard error of $0.27 \%$ for $\delta^{18} \mathrm{O}_{\text {sO4 }}$ values (Table 1).

\subsubsection{Stable isotope analysis of anhydrite and $C A S$}

The methodology for extraction of CAS from carbonate samples followed that of Gill et al. (2007). Approximately 100 to $400 \mathrm{~g}$ of carbonate rock for each sample was powdered in a shatter box. Each sample was rinsed twice with $600 \mathrm{~mL}$ of deionized water $(18 \mathrm{M} \Omega \cdot \mathrm{cm})$ lasting 24 hours each, with occasional stirring. The deionized water rinse removed soluble sulfates present in the rock sample. After each rinse, the water was carefully decanted. The samples were then treated with a $4 \%$ sodium hypochlorite solution, mixed well, and allowed to react for 48 hours with occasional stirring. This treatment removed organically-bound sulfur and metastable sulfides from the sample, including pyrite. The amount of sulfides, specifically pyrite, was not assessed prior to extraction; therefore, some 
contamination from incomplete removal of sulfides must be considered. Any contaminating sulfides could have been oxidized in the following steps. Samples were thoroughly rinsed two times with 18 $\mathrm{M} \Omega \cdot \mathrm{cm}$ water and carefully decanted. Next, a $4 \mathrm{~N} \mathrm{HCl}$ solution was slowly added to each sample, allowing for rapid effervescence. The volume of acid solution was stirred gently and brought up to $\sim 650$ $\mathrm{mL}$. Samples were allowed to digest for 7 days with occasional gentle stirring. The remaining solution was centrifuged and vacuum filtered (using $0.45 \mu \mathrm{m}$ Millipore filters) to remove any insoluble residue. Approximately $100 \mathrm{~mL}$ of saturated $\mathrm{BaCl}_{2}$ solution $(250 \mathrm{~g} / \mathrm{L})$ was added to each filtered and acidified sample. Samples were allowed to sit for 3 days to allow for complete $\mathrm{BaSO}_{4}$ precipitation from the acidified solution. The $\mathrm{BaSO}_{4}$ precipitate was separated from the solution via vacuum filtration with 0.45 $\mu \mathrm{m}$ Millipore filters, collected, and allowed to dry before the sample was powdered. The $\mathrm{BaSO}_{4} \mathrm{Samples}$ were analyzed for $\delta^{18} \mathrm{O}_{\mathrm{CAS}}$ and $\delta^{34} \mathrm{~S}_{\mathrm{CAS}}$ values in the same manner as the brine $\mathrm{BaSO}_{4}$ precipitates (see Section 3.2.1). Samples were analyzed in duplicate and had an average standard error of $0.20 \%$ for $\delta^{18} \mathrm{O}_{\mathrm{CAS}}$ and of $0.04 \%$ for $\delta^{34} \mathrm{~S}_{\mathrm{CAS}}$ (Table 2).

Sulfur isotope analysis of anhydrites was conducted at Isotope Tracer Technologies, Inc., in Waterloo, Ontario. The anhydrite samples were dissolved in dilute $\mathrm{HCl}$ solution and filtered using 0.45 $\mu \mathrm{m}$ cellulose nitrate filters. Filtered samples were passed through an ion-exchange column using Bio-Rad AG-1-X8 exchange resin to selectively collect sulfate ions from solution. The columns were washed with deionized water and the dissolved sulfate was collected. Excess $\mathrm{BaCl}_{2}$ was added to the sample solution and allowed to precipitate the $\mathrm{SO}_{4}{ }^{2-}$ ions from solution as $\mathrm{BaSO}_{4}$ for 8 hours. The solution and precipitates were acidified to a $\mathrm{pH}$ of 4 for 0.5 to 1 hour. The supernatant was removed, and the $\mathrm{BaSO}_{4}$ precipitate was collected via vacuum filtration with several deionized water rinses and allowed to dry. Barium sulfate samples $(0.20 \mathrm{mg})$ were loaded into tin capsules with $4 \mathrm{mg}$ of $\mathrm{Nb}_{2} \mathrm{O}_{5}$. The tin capsules were loaded into an autosampler connected to a Carlo Erba NA 1500 Elemental Analyzer for flash combustion at $1,100{ }^{\circ} \mathrm{C}$. The combusted gas $\left(\mathrm{SO}_{2}\right)$ was transferred via a He stream through a water trap 
and into a GV Optima-558 dual-inlet IRMS for isotope analysis of the $\delta^{34} \mathrm{~S}$ values. The laboratory analytical precision is $\pm 0.3 \%$ o $(\mathrm{V}-\mathrm{CDT})$.

\section{RESULTS}

\subsection{Dissolved sulfate in the Mt. Simon and Ironton-Galesville brines}

The zone-averaged $\delta^{18} \mathrm{O}_{\mathrm{SO} 4}$ values in the Mt. Simon brines range from $13.1 \%$ to $15.4 \%$ with an overall standard deviation of $0.7 \%$ and an isotopic range of $2.3 \%$ throughout the Mt. Simon (Table 1). The $\delta^{34} \mathrm{~S}_{\mathrm{SO} 4}$ values in the Mt. Simon range from $33.2 \%$ to $39.0 \%$ with an overall standard deviation among the eight zones of $2.0 \%$. In the Ironton-Galesville, $\delta^{18} \mathrm{O}_{\mathrm{SO} 4}$ values average $13.0 \%$, with a difference of $0.3 \%$. The average $\delta^{34} \mathrm{~S}_{\mathrm{SO} 4}$ value in the Ironton-Galesville is $22.7 \%$, with a difference of 0.2\% . Dissolved sulfate concentrations range from $254 \mathrm{mg} / \mathrm{L}$ to $917 \mathrm{mg} / \mathrm{L}$, with an average of $439 \mathrm{mg} / \mathrm{L}$ for the entire Mt. Simon. Dissolved sulfate concentrations average 1,209 mg/L in the Ironton-Galesville samples. Despite a TDS gradient that is greatest in the Lower Mt. Simon and decreases upward through the Ironton-Galesville, the greatest dissolved sulfate concentrations are in the Ironton-Galesville brine, whereas concentrations decrease steadily in the Upper Mt. Simon and are lowest in the Lower Mt. Simon (Table 1; Fig. 3).

\subsection{Eau Claire and Bonneterre Formation CAS and anhydrites}

The $\delta^{34} \mathrm{~S}_{\mathrm{CAS}}$ and $\delta^{18} \mathrm{O}_{\mathrm{CAS}}$ values in the Eau Claire and Bonneterre Formations for CAS isotopically covary and have an apparent stratigraphic relationship (Table 2 ). The $\delta^{34} \mathrm{~S}_{\mathrm{CAS}}$ values show a range of $12.0 \%$ between the sites, and the $\delta^{18} \mathrm{O}_{\mathrm{CAS}}$ values show a range of $4.0 \%$. The most enriched CAS samples are the Eau Claire C-8948 and Bonneterre Formation Buick Mine samples, which originate from the carbonate sands within the upper portion of the stratigraphic section. The Eau Claire C-8948 sample has a $\delta^{34} \mathrm{~S}_{\mathrm{CAS}}$ value of $21.3 \%$ and a $\delta^{18} \mathrm{O}_{\mathrm{CAS}}$ value of $1.4 \%$. The Buick Mine sample, also from the carbonate sands, shows a $\delta^{34} \mathrm{~S}_{\mathrm{CAS}}$ value of $14.7 \%$ and a $\delta^{18} \mathrm{O}_{\mathrm{CAS}}$ value of $0.1 \%$. The Eau Claire C-8949 samples were collected from deeper in the carbonate section, likely from the fore reef to reef deposits. 
These values cluster together from $\delta^{34} \mathrm{~S}_{\mathrm{CAS}}$ values ranging from $11.2 \%$ to $9.3 \%$ and $\delta^{18} \mathrm{O}_{\mathrm{CAS}}$ values ranging from $-1.5 \%$ to $-2.6 \%$.

Sulfur isotopes of three anhydrite samples from the Eau Claire Formation were measured at two different drill site locations. At VW1, two samples were taken from a depth of 1,681 $\mathrm{m}$ from siliciclastic sediments $0.5 \mathrm{~m}$ above the conformable contact with the Mt. Simon Sandstone. At VW1, anhydrite samples had $\delta^{34} \mathrm{~S}_{\mathrm{SO} 4}$ values of $14 \%$. A third anhydrite sample from a drill core in Marion County, Illinois, taken from a shaley dolomitic carbonate unit in the upper section of the formation at a depth of 2,366 $\mathrm{m}$ also had a value of $14 \%$ (Table 2).

\section{DISCUSSION}

\subsection{Isotope salt effect on oxygen}

Dissolved salts in water can alter the oxygen and hydrogen isotope partitioning between water and other dissolved ions because of the hydration of ions, or the so-called isotope salt effect or isotope activity (Horita et al., 1993a,b, 1994; Boschetti, 2013). The salt effect on isotope partitioning was utilized by Labotka et al. (2015) to isotopically evaluate the Mt. Simon and Ironton-Galesville brine environment. Here, we address the influence this salt effect has on the oxygen isotope systematics of the brine and dissolved sulfate within the Cambrian-hosted brines. The interactions between dissolved electrolyte ions and water molecules create an isotope partitioning effect on the $\delta^{18} \mathrm{O}$ values of the brine available for physicochemical reactions, such as evaporation and water-rock interaction (Horita et al., 1994). The salt isotope effects for the Mt. Simon and Ironton-Galesville brine chemistry depend on temperature and the relative abundance of salts, particularly dissolved $\mathrm{NaCl}, \mathrm{CaCl}_{2}, \mathrm{MgCl}_{2}, \mathrm{KCl}, \mathrm{Na}_{2} \mathrm{SO}_{4}$, and $\mathrm{MgSO}_{4}$. The salt effect for $\delta^{18} \mathrm{O}_{\text {brine }}$ is dependent on the type of cation in the dissolved salt and can be positive or negative (Horita et al., 1993, 1994), but overall the Na-Ca-Cl-type brines in this study result in $\delta^{18} \mathrm{O}_{\text {activity }}$ values slightly more depleted than $\delta^{18} \mathrm{O}_{\text {composition }}$ values (Table 1).

The salt effect should be considered when evaluating the isotope difference between $\delta^{18} \mathrm{O}_{\text {brine }}$ values and dissolved $\delta^{18} \mathrm{O}_{\mathrm{SO} 4}$ values. Hydration spheres stabilize the sulfate ion, creating sulfate water 
clusters $\left[\mathrm{SO}_{4}{ }^{2-} \bullet\left(\mathrm{H}_{2} \mathrm{O}\right)_{\mathrm{n}}\right]$ where $\mathrm{n} \geq 3$ (Wang et al., 2000; Wong and Williams, 2003; Zhou et al., 2006). When examining the fractionation factor, $\alpha$, in solution, the overall fractionation between hydrated $\mathrm{SO}_{4}{ }^{2-}$ - $\left(\mathrm{H}_{2} \mathrm{O}\right)_{n}$ and bulk water is more important than changes in the fractionation between the $\mathrm{SO}_{4}{ }^{2-}$ skeleton and bulk water (Zeebe, 2010). In this investigation, we did not assess the individual salt effect on the dissolved sulfate, but we do address the overall salt effect on physiochemical reactions with the brines. The effects of geochemical interactions between the brines and other phases involving processes such as evaporation, mineral precipitation, and water-rock interaction are more applicably addressed by using water isotope activities. The brine isotope activities for $\delta^{18} \mathrm{O}$ were calculated using the experimental parameters and methodology of Horita et al. (1993a,b, 1994). The salt effect on brines is an additive property. Therefore, effects from individual salts can be summed to assess the overall salt effect on the isotopes in the brine. Single salt effects are evaluated using the equation:

$10^{3} \ln \Gamma=m(a+b / T)$,

where $\Gamma$ is the isotope ratio of the salt divided by the isotope ratio of the pure vapor, $m$ is the molality, $T$ is temperature in Kelvin $(\mathrm{K})$, and $a\left(\right.$ molality $\left.^{-1}\right)$ and $b\left(\mathrm{~K} \times\right.$ molality $\left.^{-1}\right)$ are experimental parameters. Environmental temperature was evaluated between 50 and $42{ }^{\circ} \mathrm{C}$ for the Mt. Simon and IrontonGalesville brines, which are the average downhole temperatures measured on site. Multiple salts are evaluated according to the following equation:

$$
\begin{aligned}
10^{3} \ln \Gamma_{\text {mixed salt soln }} & =\Sigma 10^{3} \ln \Gamma_{\text {mixed salt soln }} \\
& =\Sigma\left[m_{i}\left(a_{i}+b_{i} / T\right)\right],
\end{aligned}
$$

where $i$ represents the individual salts. Salt concentrations were estimated based on the molar concentration of individual ions in the brine. The dominant salts in the Mt. Simon brines are $\mathrm{NaCl}$ and $\mathrm{CaCl}_{2}$. The minor salts $\mathrm{KCl}, \mathrm{MgCl}_{2}, \mathrm{Na}_{2} \mathrm{SO}_{4}$, and $\mathrm{MgSO}_{4}$ were also evaluated. The estimated delta value $(\delta)$ for the isotope activity is evaluated using the relationship between isotope activity and composition scales:

$\delta_{\text {activity }} \cong \delta_{\text {composition }}+10^{3} \ln \Gamma$. 
The isotope salt effect or isotope activity was calculated for the $\delta^{18} \mathrm{O}$ and $\delta \mathrm{D}$ values for each zone in the Mt. Simon (zones 2-9) and Ironton-Galesville (zones 10-11) brines (Table 1). Overall, the $\Delta^{18} \mathrm{O}_{\text {composition- }}$ activity was $<1 \%$ for the Mt. Simon and Ironton-Galesville brines.

\subsection{Conditions of oxygen isotope equilibrium in the $\mathrm{SO}_{4}-\mathrm{H}_{2} \mathrm{O}$ system}

The oxygen isotope systematics of sulfate in natural environments remain enigmatic. Considering an average environmental temperature range of 0 to $35^{\circ} \mathrm{C}$, the calculated fractionation between sulfate oxygen and the water source is $\sim 20 \%$ to $28 \%$ (Zeebe, 2010 ). The measured range of sulfate oxygen isotopes from barite and gypsum assumed to form under surface condition temperatures (e.g., marine environments) extends well outside this calculated range, as do measured CAS values (Claypool et al., 1980; Kampschulte and Strauss, 2004; Gill et al., 2007; Rennie and Turchyn, 2014). Without the presence of a catalyst such as microbial mediation, isotope equilibrium between oxygen isotopes of the source water and the dissolved sulfate require significant time under low temperature and near-neutral $\mathrm{pH}$ conditions. Chiba and Saki (1985) reported that the time required for a 97\% sulfate-water isotope equilibrium in ambient seawater $\left(\mathrm{pH} 8\right.$, temperature of $\left.4{ }^{\circ} \mathrm{C}\right)$ and deep-sea interstitial water is $10^{7}-10^{9}$ years. Nonequilibrium isotopic deviation of $\delta^{18} \mathrm{O}_{\mathrm{SO} 4}$ can be due to effects from source water mixing during diagenesis, dolomitization of carbonates, and effects from bacterial sulfate reduction (BSR; e.g., Rennie and Turchyn, 2014; Present et al., 2015). Biological processes that produce sulfite as an intermediate, such as BSR, disproportionation of elemental sulfur and thiosulfate, and sulfide oxidation, can also alter the $\delta^{18} \mathrm{O}$ values of sulfate. Sulfite more readily exchanges oxygen isotopes with water (van Stempvoort and Krouse, 1994; Wankel et al., 2014), and the resultant sulfate that forms from the sulfite will largely retain that isotope signature (Turchyn et al., 2010). Therefore, at surface conditions, groundwater in natural environments is often part of a hydrologically open system in which the oxygen isotopes of the aqueous $\mathrm{SO}_{4}-\mathrm{H}_{2} \mathrm{O}$ system are not at isotopic equilibrium.

Wortmann et al. (2007) discussed five possible mechanisms for oxygen isotope exchange in dissolved sulfate-water systems applicable to marine environments. These mechanisms, which are not 
mutually exclusive, involve (1) kinetic isotope fractionation, (2) formation of metabolic intermediates such as metastable sulfite, (3) a combination of (1) and (2), (4) $\mathrm{H}_{2} \mathrm{~S}$ oxidation to $\mathrm{S}^{0}$ followed by disproportionation of elemental sulfur to $\mathrm{SO}_{4}{ }^{2-}$ and sulfide, often accompanied by microbial mediation, and (5) oxidation of sulfide to sulfate via water or dissolved $\mathrm{O}_{2}$. Sulfate ions are the predominant sulfur species in low-enthalpy (temperature $<150{ }^{\circ} \mathrm{C}$ ) solutions at near neutral or basic $\mathrm{pH}$ conditions (Boschetti, 2013). Geothermometric equations using empirical and theoretical approaches for analyzing the $\mathrm{SO}_{4}{ }^{2-}-$ $\mathrm{H}_{2} \mathrm{O}$ system are used to evaluate oxygen isotopes in the brine sulfate, which takes into account isotope activities associated with the salinity effect of these brines. Oxygen isotope fractionation between brines and dissolved sulfate offers insight into fluid interactions and equilibration (e.g., Boschetti, 2013). This approach is appropriate when the dominant sulfur species is sulfate. Sulfate was the only sulfur species detected in the Cambrian strata from the VW1 well bore, and no $\mathrm{H}_{2} \mathrm{~S}$ was detected (Panno et al., 2013). Very little modern microbial activity has been identified that could affect the brines and dissolved sulfate oxygen isotope fractionation (Dong et al., 2013), although experiments suggest oxygen isotope equilibration between abiotic systems and those influenced by microbial sulfate reduction result in a similar magnitude of fractionation (Zeebe, 2010). Zeebe (2010) established a theoretical calculation for abiotic stable oxygen isotope fractionation between dissolved sulfate and water that accounts for temperature by using the equation

$10^{3} \ln \alpha_{(\text {SO4-H2O)theoretical }}==\left[\left(2.68 \times 10^{6}\right) / T^{2}\right]-7.45$,

where $T$ is temperature measured in Kelvin and $\alpha$ is the isotope fractionation factor of oxygen between sulfate and water. Given the environmental temperatures in Table 1, the theoretical stable oxygen isotope fractionation between dissolved sulfate and water ranges between 18.2\%o and 19.0\%o for the Mt. Simon brines and between $19.4 \%$ and $19.5 \%$ for the Ironton-Galesville brines.

Halas and Pluta (2000) established an empirical calibration for low temperature geothermal brines using the following equation:

$10^{3} \ln \alpha_{(\text {SO4-H2O)empirical }}=\left[\left(2.41 \times 10^{6}\right) / T^{2}\right]-5.77$, 
where the same variables apply as in Eq. (5). Given the environmental temperatures in Table 1, the empirical stable oxygen isotope fractionation between dissolved sulfate and water ranges between 17.3\%o and $18.0 \%$ for the Mt. Simon brine and between $18.5 \%$ and $18.3 \%$ for the Ironton-Galesville brine.

The measured oxygen isotopes of the brines and associated sulfate appear close to isotope equilibrium for the Lower Mt. Simon Formation (Fig. 4). Considering the relation $10^{3} \ln \alpha \approx \delta_{\mathrm{a}}-\delta_{\mathrm{b}}$

where $\delta_{\mathrm{a}}$ is dissolved $\delta^{18} \mathrm{O}_{\mathrm{SO} 4}$ and $\delta_{\mathrm{b}}$ is $\delta^{18} \mathrm{O}_{\text {activity }}$ of the brine, then the difference between measured and theoretical values for each zone in the Lower Mt. Simon is $<1 \%$ and the difference between measured and empirical values for each zone is $<1.5 \%$ ( $\left(\Delta^{18} \mathrm{O}_{\text {activity-sulfate; }}\right.$ Table 1$)$. The likely mechanism for oxygen isotope exchange of marine sulfates involves $\mathrm{H}_{2} \mathrm{~S}$ oxidation to $\mathrm{S}^{0}$ followed by disproportionation of elemental sulfur to $\mathrm{SO}_{4}{ }^{2-}$ and sulfide (Wortmann et al., 2007). This process is invoked to explain the $\delta^{18} \mathrm{O}_{\mathrm{SO} 4}$ of interstitial waters and the $\delta^{18} \mathrm{O}_{\mathrm{SO} 4}$ value of ocean water (e.g., Turchyn and Schrag, 2006; Turchyn et al., 2006). This process is often facilitated by the formation of metastable sulfite as an intermediate via microbial mediation, which allows rapid oxygen isotope exchange with ambient water (Böttcher et al., 2005). Because no $\mathrm{H}_{2} \mathrm{~S}$ and very little microbial activity was detected in the Mt. Simon brines, the oxidation of available $\mathrm{H}_{2} \mathrm{~S}$ is assumed to be complete if ocean sulfate is the source of dissolved sulfate in the brines. The dissolved $\delta^{18} \mathrm{O}_{\mathrm{SO} 4}$ value is intrinsically tied to the $\delta^{18} \mathrm{O}_{\text {brine }}$ value (Mizutani and Rafter, 1973; Brunner et al., 2005). Without the presence of $\mathrm{H}_{2} \mathrm{~S}$ or a catalyst, such as microbial activity, the near-isotope equilibrium of the $\mathrm{SO}_{4}-\mathrm{H}_{2} \mathrm{O}$ system of the Lower Mt. Simon brine suggests minimal mixing with other brines over at least the last $10^{5}$ years and possibly tens of millions of years (Lloyd, 1968; Chiba and Sakai, 1985; Halas and Pluta, 2000; Zeebe, 2010; Boschetti, 2013). Otherwise, the addition of groundwater with different $\delta^{18} \mathrm{O}$ compositions would have resulted in disequilibrium of the $\mathrm{SO}_{4}-\mathrm{H}_{2} \mathrm{O}$ isotope system, and, without the presence of $\mathrm{H}_{2} \mathrm{~S}$ or microbial activity, would require significant time for isotope equilibration. 
Oxygen isotopes of the Upper Mt. Simon zones 8 and 9 and Ironton-Galesville zones 10 and 11 appear to be less in equilibrium with theoretical and empirical estimates for $\delta^{18} \mathrm{O}_{\mathrm{SO} 4}$ values (Fig. 4). The $\delta^{18} \mathrm{O}_{\text {activity }}$ and the $\delta^{18} \mathrm{O}_{\mathrm{SO} 4}$ exhibit $\sim 2 \%$ to $3 \%$ difference in oxygen isotope values versus theoretical or empirical values. This result suggests that the Ironton-Galesville and Upper Mt. Simon brines are less isolated or may have reacted with minerals within the Eau Claire Formation (Halas and Pluta, 2000; Zeebe, 2010; Boschetti, 2013). Nevertheless, the external groundwater mixing events or sulfate reactions for the Ironton-Galesville and Upper Mt. Simon brines appear unrelated, as shown by the distinct isotopic differences in the dissolved $\delta^{34} \mathrm{~S}_{\mathrm{SO} 4}$ values between the two sandstone units (Table 1; Fig. 5).

\subsection{Preservation potential of Cambrian CAS and evaporite deposits}

The sulfate $\delta^{18} \mathrm{O}$ and $\delta^{34} \mathrm{~S}$ values of CAS have been shown to reliably represent the isotopic composition of coeval seawater sulfate with no apparent fractionation for either oxygen (Cortecci and Longinelli, 1971; Newton et al., 2004) or sulfur (Burdett et al., 1989; Kampschulte and Strauss, 2004). With the absence of evaporite deposits, one potential source of sulfate in the Mt. Simon brines is CAS or associated seawater sulfate in the carbonate facies of the overlying Cambrian-aged Eau Claire and Bonneterre Formations. The relatively enriched $\delta^{34} \mathrm{~S}_{\mathrm{SO} 4}$ values of the Cambrian oceans suggest an increased burial of sulfide and enhanced turnover of sulfate via BSR compared with most of Phanerozoic history (Kampschulte and Strauss, 2004). Seawater sulfate concentrations during the Cambrian were also suspected to be lower than in modern oceans, which would make the isotopic reservoir of $\delta^{34} \mathrm{~S}_{\mathrm{SO} 4}$ of the seawater more sensitive to changes in sources of sulfur and the sulfur cycle (Hough et al., 2006). Recent studies have used CAS as a more reliable measure of sulfate isotopes indicative of marine environments (e.g., Kampschulte and Strauss, 2004; Newton et al., 2004; Gill et al., 2007, 2011), especially where evaporite deposits are scarce or nonexistent. The original $\delta^{34} \mathrm{~S}_{\mathrm{CAS}}$ value has been shown to survive two types of diagenesis: (1) marine diagenesis with evolving pore-water sulfate and authigenic calcite precipitation resulting from intense BSR activity (Lyons et al., 2004; Rennie and Turchyn, 2014), and (2) meteoric diagenesis despite significant isotope changes to the carbonate isotopes (Gill et al., 2008). 
Nevertheless, no studies have investigated the preservation potential of $\delta^{34} \mathrm{~S}_{\mathrm{CAS}}$ values when the carbonates have undergone dolomitization with ore fluids.

\subsubsection{Sulfate isotope values}

The Eau Claire and Bonneterre carbonates that were analyzed in this study have been extensively dolomitized. A reasonable assumption is that because of the dolomitization of these samples, the CAS trapped within the recrystallized carbonate lattice will mainly exhibit the isotopic signatures of the dolomitizing fluids, especially if these fluids were sulfur rich, such as the MVT fluids. The stratigraphic position of the CAS samples within the Eau Claire or Bonneterre Formation (Table 2) appears to influence the isotope trends observed in the CAS. Rogers and Davis (1977) described the Bonneterre Formation at the Buick Mine as follows: the top one-third of the formation consists of carbonate sands and the bottom two-thirds consist of the fore reef, reef, and back reef deposits. The CAS samples from the Buick Mine and C-8948 carbonate are dark brown and are likely part of the carbonate sands; samples from C-8949 are light gray and are likely from the fore reef to reef section of the carbonate formation (Rogers and Davis, 1977).

The original trace CAS of the Cambrian-aged marine carbonates appear to have been replaced. The $\delta^{34} \mathrm{~S}_{\mathrm{CAS}}$ and $\delta^{18} \mathrm{O}_{\mathrm{CAS}}$ values are significantly isotopically different and variable compared with the expected Cambrian marine sulfate values (e.g., Claypool et al., 1980; Fig. 5). The $\delta^{34} \mathrm{~S}_{\mathrm{CAS}}$ and $\delta^{18} \mathrm{O}_{\mathrm{CAS}}$ values also covary with stratigraphic position within the carbonate sequence, suggesting lithological controls on MVT mineralization. Negligible isotope fractionation occurs in $\delta^{34} \mathrm{~S}$ values as sulfide oxidizes to sulfate minerals or aqueous phases and therefore reflects the isotopic values of the parent sulfide (Seal, 2006; Balci et al., 2007; Heidel and Tichomirowa, 2011). The $\delta^{34} \mathrm{~S}_{\mathrm{CAS}}$ values analyzed from the Eau Claire and Bonneterre Formations exhibit an isotope range of $21.3 \%$ to $9.3 \%$. Ore fluids associated with the Viburnum Trend/Old Lead Belt emplaced during the Late Pennsylvanian-Early Permian exhibit a general sulfide $\delta^{34} \mathrm{~S}$ range of $5 \%$ to $20 \%$ (Leach et al., 2010). Specifically, ore fluids contemporary with the Viburnum Trend/Old Lead Belt pulse show $\delta^{34}$ S-sulfide values of $0 \%$ to $21 \%$ from the Buick Mine 
(Sverjensky, 1981). This $\delta^{34} \mathrm{~S}$ range of ore sulfides corresponds very well to the observed $\delta^{34} \mathrm{~S}_{\mathrm{CAS}}$ values measured from the Eau Claire and Bonneterre carbonates (Table 2; Fig. 5).

Anhydrite samples from the Eau Claire Formation, two at VW1 (1,681 m) and one from Marion County, Illinois $(2,366 \mathrm{~m})$, were analyzed for $\delta^{34} \mathrm{~S}$ values. All three samples averaged $14 \%$ (Table 2). The $\delta^{34} \mathrm{~S}_{\mathrm{SO} 4}$ values of anhydrite in the Eau Claire Formation fall directly in range with the measured $\delta^{34} \mathrm{~S}_{\mathrm{CAS}}$ values of the Eau Claire, suggesting these evaporite minerals are also associated with the MVT fluids. The two samples at VW1 were collected $\sim 0.5 \mathrm{~m}$ above the transition of fluvial, playa, and eolian deposits of the Upper Mt. Simon ( 1,681 m depth) into the marine and tidal deposits at the base of the Eau Claire Formation. This result suggests that the MVT ore fluids had a significant effect on the entire Eau Claire Formation, including at the conformable contact with the Mt. Simon Sandstone. The lack of carbonate material from VW1 prevents detailed analysis of CAS to determine the extent and pervasiveness of the ore fluids concerning carbonate recrystallization.

The oxygen-isotope systematics of CAS remain poorly understood even in well-preserved environments (Rennie and Turchyn, 2014). With the emplacement of MVT fluids, the fractionation between $\delta^{18} \mathrm{O}$ of the ore fluid and $\delta^{18} \mathrm{O}_{\mathrm{CAS}}$ is largely unpredictable because of an unconstrained fluid temperature at the time of dissolved sulfate formation, unknown $\delta^{18} \mathrm{O}$ values of dolomitizing fluids, and an unknown time between dissolved sulfate formation and dolomite recrystallization. The extent of $\delta^{18} \mathrm{O}$ isotope exchange between the $\delta^{18} \mathrm{O}_{\mathrm{SO} 4}$ of dissolved $\mathrm{SO}_{4}{ }^{2-}{ }_{\text {(aq) }}$ clusters and mineralizing fluids prior to dolomitization of CAS is also unknown but is expected to be minimal if dolomite recrystallization occurred relatively rapidly (e.g., Lloyd, 1968; Chiba and Sakai, 1985; Holser et al., 1988). The $\delta^{18} \mathrm{O}_{\mathrm{CAS}}$ and $\delta^{34} \mathrm{~S}_{\mathrm{CAS}}$ values of these Late Cambrian-aged carbonates show a strong positive regression, $\mathrm{R}^{2}=0.94$ (Fig. 5). This linear relationship suggests kinetic fractionation of sulfur and oxygen isotopes dependent on temperature, evolving ore fluids, and microbial activity (Aharon and Fu, 2000; Wortmann et al., 2007). Oxidative pyrite weathering usually produces $\delta^{18} \mathrm{O}$ values of $-4 \%$ to $+2 \%_{0}$ in marine settings (Turchyn and Schrag, 2004), and seawater is suspected to be the original water source for the MVT brines (Bethke, 
1986; Kesler et al., 1997). The $\delta^{18} \mathrm{O}_{\mathrm{CAS}}$ values of the Eau Claire and Bonneterre Formation carbonates ($2.6 \%$ to $+1.4 \%$ ) fall within this range and suggest the source of CAS sulfate is oxidation of the MVT sulfides from the Late Pennsylvanian-Early Permian ore pulses in marine waters (Table 2).

The possibility exists that pyrite was not completely removed from the CAS samples in the extraction process and was oxidized, resulting in an isotopic value falling between the more depleted $\delta^{34} \mathrm{~S}$ value of the sulfide source and the original Cambrian seawater value $(+30 \%)$. Although small isotope discrepancies could not be discerned, this possibility is considered and thought to have had minor effects on the CAS results. The distribution of $\delta^{34} \mathrm{~S}_{\mathrm{CAS}}$ values appears to vary stratigraphically (Table 2). The samples with isotopically heavier $\delta^{34} \mathrm{~S}_{\mathrm{CAS}}$ values, C-8948 and Buick Mine, exhibit a dark gray-brown mottled texture and were collected from the top of the carbonate formation, which is part of the carbonate sands environment. The three C-8949 samples exhibit a light gray mottled dolomite texture and were collected from the fore reef to reef section of the carbonate formation (Rogers and Davis, 1977). These three C-8949 samples have isotopically lighter $\delta^{34} \mathrm{~S}_{\mathrm{CAS}}$ values compared with those from the carbonate sands. The $\delta^{34} \mathrm{~S}_{\mathrm{CAS}}$ values suggest the MVT ore fluid movement in the carbonate formation may have been stratigraphically controlled. The strong correlation between $\delta^{34} \mathrm{~S}_{\mathrm{CAS}}$ and $\delta^{18} \mathrm{O}_{\mathrm{CAS}}$ supports the concept of a wholesale replacement for the CAS (Fig. 5) rather than a mixing scenario between original Cambrian seawater and MVT ore fluids. If the CAS sulfate was a result of mixing between Cambrian seawater and sulfide oxidation, then the $\delta^{18} \mathrm{O}_{\mathrm{CAS}}$ values would likely exhibit more enriched ${ }^{18} \mathrm{O}$ values representative of Cambrian seawater sulfate.

Several studies suggest that initial dolomitization of these Cambrian-aged carbonates occurred early during diagenesis. Later, the dolomites underwent neomorphic recrystallization and cementation during exposure to MVT fluids (Shelton et al., 2009; Gregg and Shelton, 2012). The isotopic evidence presented here suggests that significant chemical alteration to the carbonate composition occurred even within trace amounts of sulfate within the carbonate lattice. Therefore, the later ore-pulse-influenced dolomitization of these carbonates may have been more extensive than previously considered. 


\subsubsection{Lack of evidence for MVT fluids in Mt. Simon and Ironton-Galesville brines}

The dissolved sulfate of Mt. Simon brines shows no isotopic evidence of interaction with the sulfide from the ore pulses. This result suggests two basic scenarios. For scenario one, if these ore fluids never entered the Mt. Simon brines, it may provide a minimum timing of isolation. This does not determine whether the sulfate of the Mt. Simon brines originated from basin-derived Cambrian seawater or externally derived dissolved sulfates, such as those in the Michigan Basin. For scenario two, the sulfate in the Mt. Simon brines originated externally after traces of MVT ore fluid sulfides had been removed from the brines.

The question arises regarding why the Mt. Simon brines do not show geochemical influences related to sulfur from the MVT mineralizing events. Panno et al. (2013) suggested, based on brine $\mathrm{Cl} / \mathrm{Br}$ ratios, that MVT fluids were a possible contribution to the Mt. Simon brines. Evidence of MVT fluids is present in the conformably overlying Eau Claire and Bonneterre Formations. MVT fluid migration is also observed in the Lamotte Sandstone (Snyder and Gerdemann, 1968; Gregg and Shelton, 2012). So what could have sheltered the Mt. Simon Sandstone brines from effects of MVT fluid migration?

Cambrian-hosted MVT ore deposits of southeastern Missouri, including the Old Lead Belt/Fredericktown/Viburnum districts, are concentrated along the eastern and western flanks of the Proterozoic igneous complex of the St. Francois Mountains (Gregg and Shelton, 2012). Mineralization from the MVT fluids appears to have been controlled by the algal bioherm-grainstone facies that formed around these igneous Proterozoic topographic highs, which formed islands in the epeiric seas of the Late Cambrian. The high-porosity reef rock of the Late Cambrian carbonates provided adequate void space for mineralization, which was disseminated throughout suitable facies (Gerdemann and Myers, 1972; Wilson and Jordan, 1983; Leach et al., 2010).

Bethke (1986) presented a gravity-driven flow model for migration of the MVT fluids within the Illinois Basin. The average density of the Mt. Simon brines is $\sim 195 \mathrm{~g} / \mathrm{L}$. The estimated average density for the MVT fluids ranges from 60 to $180 \mathrm{~g} / \mathrm{L}$ (Basuki and Spooner, 2002). If the gravity-flow model was the main mechanism for fluid movement, then the density of the Mt. Simon brines may have 
prevented MVT fluid flow into this deep sedimentary basin. This event suggests a potential age of isolation for the Mt. Simon brines from at least the Late Pennsylvanian to early Permian. With sulfate concentrations in the Mt. Simon brines ranging from $\sim 900$ to $250 \mathrm{mg} / \mathrm{L}$ (Table 1), relatively small concentrations of dissolved sulfide/sulfate in migrating fluids could alter the isotope composition of the dissolved sulfate in the Mt. Simon brines.

Quartz cementation in the Mt. Simon Sandstone progressed during burial with little change in the $\delta^{18} \mathrm{O}$ value of the burial fluids, which was estimated to be Cambrian seawater with a value of $-3 \%$ (Lohmann and Walker, 1989; Came et al., 2007; Jaffrés et al., 2007). Quartz cementation within the Illinois Basin was estimated to have begun at $~ 450$ Ma and continued until $~ 250 \mathrm{Ma}$. This cementation progressed with increasing temperature and pressure from burial but without significant fluid flow (Pollington et al., 2011; Hyodo et al., 2014) and therefore with no significant changes to brine $\delta^{18} \mathrm{O}$ values. This increased cementation with burial was observed in the Mt. Simon Sandstone, Eau Claire Formation, and St. Peter Sandstone at the study site. It is also worth restating that the Eau Claire Formation at VW1 is predominantly siliciclastic siltstones and shales and becomes more carbonaceous progressing southwest toward the St. Francis Mountains and the paleoshoreline of Laurentia (Fig. 1). Quartz cementation possibly occurred during or soon after initial movement of the MVT fluids. This cementation, which terminated at $\sim 250 \mathrm{Ma}$, may have sufficiently reduced MVT fluid flow via reduced permeability to prevent these ore fluids from penetrating into the Mt. Simon Sandstone. As a result, the brief MVT fluid migration, with an estimated duration of $\sim 200,000$ years (Rowan and Goldhaber, 1995), possibly never migrated into the Mt. Simon basin at the study site, partly because of progressive in situ quartz cementation, especially at lower depths and greater pressures.

The brine from Ironton-Galesville Sandstone also does not suggest influences from these MVT ore pulse fluids. If MVT ore fluids did affect the Ironton-Galesville Sandstone, then the emplacement of dissolved sulfate in the brine from the Ironton-Galesville Sandstone at VW1 may have occurred after the MVT ore fluid pulse, or these ore fluid signatures may have sufficiently washed out of the dissolved 
sulfate component of the brine over time. Sulfur isotope analysis of secondary pyrite that occurs within the Ironton-Galesville Sandstone (Emich, 1966) may indicate the presence or absence of MVT fluids.

\subsection{Potential origins of Mt. Simon and Ironton-Galesville brines}

\subsubsection{Connate water and meteoric water}

The $\delta^{34} \mathrm{~S}_{\mathrm{SO} 4}$ and $\delta^{18} \mathrm{O}_{\mathrm{SO} 4}$ values in the Mt. Simon brines are indicative of values observed from Cambrian marine sulfates (Claypool et al., 1980; Kampschulte and Strauss, 2004). Considering the $\delta^{34} \mathrm{~S}$ of sulfate minerals, minimal fractionation occurs between gypsum and dissolved sulfate:

$\Delta_{\text {gypsum-sulfate }}=\delta^{34} \mathrm{~S}_{\text {gypsum }}-\delta^{34} \mathrm{~S}_{\text {sulfate }}=+1.65 \%$

(Thode and Monster, 1965). Therefore, the $\delta^{34} \mathrm{~S}$ value of the evaporite closely approximates the dissolved $\delta^{34} S$ value of the parent fluid. Present-day seawater sulfate has a constant $\delta^{34} S$ value of $\sim 20.1 \%$ (Bottrell and Newton, 2006), whereas average Cambrian seawater sulfate $\delta^{34} \mathrm{~S}$ values are estimated to be $\sim 35 \%$ o (Kampschulte and Strauss, 2004). After the Cambrian, seawater $\delta^{34} \mathrm{~S}_{\mathrm{SO} 4}$ values generally decreased over time. The isotopically enriched $\delta^{34} \mathrm{~S}_{\mathrm{SO} 4}$ values of seawater are largely unique to the period from the Cambrian to the early Ordovician. The variability of $\delta^{34} \mathrm{~S}$ in primary marine sulfate generally arises from (1) the effects of bacterial reduction of sulfate to sulfide, resulting in variable enrichment of ${ }^{34} \mathrm{~S}$ in the residual sulfate in evaporative brines; (2) the precipitation and weathering of evaporites; (3) contributions of mantle sulfur along mid-ocean ridges; and (4) the rate of pyrite burial and changes in ocean anoxia (Kampschulte and Strauss, 2004; Faure and Mensing, 2005; Hough et al., 2006). These effects are often preserved in sulfate minerals such as anhydrite.

The $\delta^{18} \mathrm{O}_{\mathrm{SO} 4}$ values of dissolved sulfate within the Lower Mt. Simon brines appear to be close to isotope equilibrium. Chiba and Sakai (1985) concluded that the oxygen isotope exchange rate between water and oceanic sulfate at near neutral $\mathrm{pH}$ and low temperatures can take several millions of years and therefore cannot be the controlling factor in the oxygen isotope composition of oceanic sulfates. The $\delta^{18} \mathrm{O}$ value of present-day seawater sulfate is 8.6\%o (Sakai and Krouse, 1971; Boschetti, 2013). Studies have shown that the oxygen isotopic composition of sulfate in modern oceans is not in isotopic equilibrium 
with seawater despite the residence time of sulfate in the oceans of $~ 21$ million years (Holser and Kaplan, 1966; Lloyd, 1968). This discrepancy is caused by several factors, including the slow rate of isotope equilibrium at low temperatures for the $\mathrm{SO}_{4}-\mathrm{H}_{2} \mathrm{O}$ system, the presence of sulfate-reducing bacteria in modern marine sediments, weathering rates, and volcanic activity, all of which continuously affect the oxidation/reduction balance of sulfate in the marine environment (Chiba and Sakai, 1985; Newton et al., 2004; Turchyn and Schrag, 2004). Therefore, for the Lower Mt. Simon brines to be at or near isotopic equilibrium for $\delta^{18} \mathrm{O}_{\mathrm{SO} 4}$ (Fig. 4), these influencing factors have likely been greatly minimized within the environment. The Upper Mt. Simon outliers in Fig. 4 (zones 8 and 9) are possibly affected by (1) a sulfate-poor fluid source that has relatively depleted the Upper Mt. Simon $\delta^{18} \mathrm{O}$ and $\delta \mathrm{D}$ values of the brine, such as an external groundwater or (2) rock-water interactions with the overlying Eau Claire Formation affecting the brine water isotopes.

The difference in $\delta^{18} \mathrm{O}_{\mathrm{SO} 4}$ and $\delta^{18} \mathrm{O}_{\text {brine }}\left(\Delta^{18} \mathrm{O}_{\text {SO4-H2O }}\right)$ could represent the effects of original bacterial sulfate reduction in the Cambrian seas, abiotic fractionation, or both. Zeebe (2010) suggested that sulfate reduction influenced by microbially mediated oxygen exchange results in oxygen isotope differences similar to abiotic equilibrium between $\mathrm{SO}_{4}{ }^{2-}$ and water. Under conditions in which bacterial sulfate reduction is predominant, the $\delta^{18} \mathrm{O}_{\mathrm{SO} 4}$ is dependent on the oxygen isotope composition of the water (Mizutani and Rafter, 1973; Brunner et al., 2005). Considering that Cambrian seawater has $\delta^{18} \mathrm{O}$ estimates of -3\% (Lohmann and Walker, 1989; Came et al., 2007; Jaffrés et al., 2007), the $\delta^{18} \mathrm{O}_{\text {brine }}$ values of the Mt. Simon (-3.6\%) may retain significant original seawater signatures. The effects of bacterial sulfate reduction on the oxygen isotopes of sulfate in modern ocean sediments are estimated to be 19\%o (Zak et al., 1980; Seal et al., 2000; Brunner et al., 2005; Turchyn et al., 2006). This estimated enrichment is similar to that observed in the Mt. Simon brines, $\Delta^{18} \mathrm{O}_{\mathrm{SO} 4-\mathrm{H} 2 \mathrm{O}} \approx 18-19 \%$, where measured brine isotope compositions are considered opposed to brine activities because original Cambrian seawater would have significantly lower TDS values than the current brines. This result is similar to the calculated abiotic equilibrium values, $10^{3} \ln \alpha_{\mathrm{SO} 4-\mathrm{H} 2 \mathrm{O}} \approx 18-19 \%$, which use brine activities because abiotic isotope 
equilibrium is a physicochemical process that requires up to tens of millions of years (Chiba and Sakai, 1985 ) and that appears to be near equilibrium under current brine TDS values (Table 1). If the effects of bacterial sulfate reduction on oxygen isotopes of sulfate in the modern oceans are similar to those in the Cambrian, then the oxygen isotopes observed in the Mt. Simon brines may represent original influences of bacterial sulfate reduction on Cambrian seawater sulfate. The range of $\delta^{18} \mathrm{O}_{\mathrm{SO} 4}$ values from Mt. Simon brines, 13.1-15.4\%o, largely agrees with oxygen isotope sulfate values of Cambrian evaporites, $13.9 \pm$ 0.51\%o (Claypool et al., 1980). This result suggests that the isotopic signatures of the dissolved sulfate in the Mt. Simon brines may share isotope enrichment mechanisms similar to sulfates in Cambrian evaporite deposits, which were likely microbially mediated. Because the abiotic and microbially mediated oxygen isotope fractionations of dissolved sulfate are similar, the original predominant path of oxygen isotope fractionation cannot be discerned. However, for the current Mt. Simon brines having very little microbial influence at or near the $\mathrm{SO}_{4}-\mathrm{H}_{2} \mathrm{O}$ isotope equilibrium, the brines are suspected to have been chemically isolated in terms of $\delta^{18} \mathrm{O}_{\text {brine }}$ and $\delta^{18} \mathrm{O}_{\mathrm{SO} 4}$ values for a significant period of time, as discussed previously.

The Ironton-Galesville Sandstone at VW1 appears to be a more hydrologically open system compared with the Mt. Simon brines. The Ironton-Galesville brine $\left(\delta^{18} \mathrm{O}=-7.2 \%, \delta \mathrm{D}=-54 \% ; n=6\right.$; Table 1) is very similar to values reported from the Cambrian-Ordovician aquifer system in northern Illinois $\left(\delta^{18} \mathrm{O}=-8 \%, \delta \mathrm{D}=-55 \% ; n=12\right.$; Siegel and Mandle, 1984) and isotopes in precipitation measured for Chicago, Illinois, at Midway Airport by the International Atomic Energy Agency from 1962 to $1979\left(\delta^{18} \mathrm{O}_{\mathrm{PPT}}=-7 \%\right.$ o, $\delta \mathrm{D}_{\mathrm{PPT}}=-51 \% ; n=192 ;$ https://nucleus.iaea.org $)$. Therefore, the water isotopes of the Ironton-Galesville brine may be influenced by modern or Pleistocene glacial recharge, or both. The dissolved sulfate in the Ironton-Galesville brine is more reminiscent than that in Mt. Simon brine of younger seawater sulfate values. The sulfate values of the Ironton-Galesville brine $\left(\delta^{34} \mathrm{~S}_{\mathrm{SO} 4}=22.7 \pm\right.$ $0.14 \%$ and $\delta^{18} \mathrm{O}_{\mathrm{SO} 4}=13.0 \pm 0.14 \%$ ) are similar to values in Devonian marine CAS $\left(\delta^{34} \mathrm{~S}_{\mathrm{SO} 4} \approx 19-24 \%\right.$ and $\delta^{18} \mathrm{O}_{\mathrm{SO} 4} \approx 14 \%$; Kampschulte and Strauss, 2004; John et al., 2010) and may be influenced by the dissolution of evaporites or CAS from younger strata in the Illinois Basin. 


\subsubsection{Fluid mixing}

No known sulfate deposits occur in the Mt. Simon Sandstone. The brines of the Mt. Simon appear to have experienced minimal mixing with intra- and extrabasinal brines of younger ages in unconfined aquifers with respect to dissolved $\delta^{34} \mathrm{~S}_{\mathrm{SO} 4}$ and brine chemistry in general (Panno et al., 2013; Labotka et al., 2015). The brines in the Ironton-Galesville Sandstone have dissolved sulfate that is isotopically distinct in terms of sulfur isotopes from the Mt. Simon Sandstone brines (Table 1; Fig. 5). The IrontonGalesville Sandstone brines have $\delta^{34} \mathrm{~S}_{\mathrm{SO} 4}$ values averaging $22.7 \%$ and are closer than Mt. Simon brines to younger seawater values observed in the Devonian (Claypool et al., 1980; Kampschulte and Strauss 2004), suggesting the Ironton-Galesville brine has mixed with seawater of younger ages. This interpretation agrees with halide and cation/halide data from previous studies (Walter et al., 1990; Panno et al., 2013). Mixing of Mt. Simon brines with younger brines would significantly decrease the measured average $\delta^{34} \mathrm{~S}_{\text {SO4 }}$ value of $34 \%$ ( $( \pm 1.7 \%$ ) to averages closer to younger Paleozoic values $(<30 \%$; Kampschulte and Strauss, 2004). Siegel (1990) reported $\delta^{34} \mathrm{~S}_{\mathrm{SO} 4}$ values of $\sim-5 \%$ for brines in younger unconfined aquifers of the Cambrian-Ordovician aquifer system of the Illinois Basin, which therefore are unlikely to be associated with the Mt. Simon or Ironton-Galesville brines.

The dissolved sulfate concentration gradient in the Mt. Simon brines is opposite all other dissolved ion concentrations. Dissolved sulfate concentrations are greatest in the Upper Mt. Simon and decrease by almost one-third in the Lower Mt. Simon (Fig. 3). Other major dissolved ions show a concentration gradient from the greatest concentrations in the Lower Mt. Simon to lower concentrations in the Upper Mt. Simon. The influx of recirculating sulfate-poor crystalline basement brines could explain the inverse trends in concentration gradients between dissolved sulfate and all other major dissolved ions.

Some Cambrian-Ordovician brines from northeastern Illinois exhibit $\delta^{34} \mathrm{~S}_{\mathrm{SO} 4}$ isotope values indicative of Cambrian sulfate (Gilkeson et al., 1981). Sulfur isotope values of $+30 \%$ to $+40 \%$ are reported in these brines. The primary source of these sulfates is thought to be dissolution of marine evaporite deposits under Lake Michigan. Gilkeson et al. (1981) also postulated that evaporite minerals are 
the primary source of the sulfur in the Cambrian-Ordovician aquifer system of west-central Illinois. Nevertheless, the difference in oxygen isotope values of the dissolved sulfate and respective brine $\delta^{18} \mathrm{O}$ isotope values from groundwater in northeastern Illinois $\left(\Delta^{18} \mathrm{O}_{\text {SO4-brine }}\right)$ is $\sim 10 \%$ o to $25 \%$ o for the aquifer system confined by the Maquoketa Shale Group in Kane County. These $\Delta \delta^{18} \mathrm{O}_{\text {SO4-brine }}$ values for northeastern Illinois exhibit a notably greater range than those at the IBDP site, where $\Delta \delta^{18} \mathrm{O}_{\text {SO4-brine }}$ values are $\sim 18 \%$ to $19 \%$. The Mt. Simon brines could share a similar sulfate source with the groundwater in northeastern Illinois, such as dissolution of marine evaporite deposits under Lake Michigan; however, these aquifers are unlikely to be hydrologically interconnected.

\section{CONCLUSIONS}

The sulfate isotopes of the Mt. Simon brines suggest a unique environment where original Cambrian seawater sulfate isotope signatures may have been preserved. The dissolved sulfate isotope values of the Mt. Simon brine are in the same isotopic range as Cambrian evaporite deposits and previously reported CAS values of Cambrian marine carbonates. Proterozoic basement topography, brine density, and progressive quartz cementation may have contributed to the relative basin isolation for the Mt. Simon. The brines of the Ironton-Galesville Sandstone are more indicative of Devonian seawater sulfate isotope values, but these brines appear more hydrologically connected to other basin brines. Pervasive MVT ore fluid migration associated with the Alleghenian-Ouachita orogeny during the Late Pennsylvanian to Early Permian and subsequent remineralization for CAS and anhydrite deposits of the Eau Claire and Bonneterre Formations did not appear to influence sulfate isotopes of the IrontonGalesville or Mt. Simon brines. The lack of evidence of MVT ore fluids within the brines of the underlying Mt. Simon or overlying Ironton-Galesville Sandstones is evident in the $\delta^{34} \mathrm{~S}_{\mathrm{SO} 4}$ and $\delta^{18} \mathrm{O}_{\mathrm{SO} 4}$ values of dissolved sulfate.

The $\delta^{18} \mathrm{O}_{\text {SO4 }}$ and $\delta^{18} \mathrm{O}_{\text {brine }}$ values in brines of the Lower Mt. Simon are close to isotopic equilibrium - this in spite of the fact that the low dissolved sulfate concentrations, especially in the Lower Mt. Simon brine (250 to $376 \mathrm{mg} / \mathrm{L}$ ), leave the sulfate isotopes especially sensitive to the influences of 
isotopically distinct outside sulfate sources such as younger Phanerozoic brines or ore fluids. Whether the dissolved sulfate isotopes of the Mt. Simon brines were influenced by abiotic or microbial mechanisms, the Lower Mt. Simon brines are suspected to have been chemically isolated in terms of $\delta^{18} \mathrm{O}_{\text {brine }}$ and $\delta^{18} \mathrm{O}_{\mathrm{SO} 4}$ values for possibly the last 20 million years (Chiba and Sakai, 1985; Holser et al., 1988). The $\delta^{18} \mathrm{O}_{\mathrm{SO} 4}$ and $\delta^{18} \mathrm{O}_{\text {brine }}$ values of the Upper Mt. Simon and Ironton-Galesville brines are farther outside the calculated range of isotopic equilibrium, possibly owing to influences from water-rock reactions with the Eau Claire or an influx of sulfate-depleted external groundwater that does not alter the $\delta^{34} \mathrm{~S}_{\mathrm{SO} 4}$ values but has not yet isotopically equilibrated with the brine $\delta^{18} \mathrm{O}_{\mathrm{SO} 4}$ values.

Overall, on the basis of this and previous studies, the likely source for the Mt. Simon brines involves a mixture of Cambrian seawater, recirculating deep-seated crystalline basement brines, and meteoric water (Panno et al. 2013; Labotka et al., 2015). The dissolved sulfate isotopes and brine oxygen isotopes of the Mt. Simon brines support evidence for original Cambrian seawater signatures. The possible preservation of such seemingly transient signatures in an aqueous environment opens new opportunities for understanding ancient oceans. 


\section{ACKNOWLEDGMENTS}

The authors thank the members of the IBDP field team who helped collect and test the fluid samples from the IBDP VW1 well, especially Abbas Iranmanesh, Bracken Wimmer, and Christopher Patterson (Illinois State Geological Survey) and staff from Schlumberger Carbon Services. The authors wish to thank Robert Mumm for assistance with sample collection and Susan Krusemark for editorial improvements and guidance. Authors would also like to thank Walton Kelly and two anonymous reviewers for thoughtful reviews of the manuscript. This research was supported by the U.S. Department of Energy through the National Energy Technology Laboratory (NETL) via the Regional Carbon Sequestration Partnership Program (contract number DE-FC26-05NT42588). 


\section{REFERENCES}

Aharon P. and Fu B. (2000) Microbial sulfate reduction rates and sulfur and oxygen isotope fractionations at oil and gas seeps in deepwater Gulf of Mexico. Geochim. Cosomochim. Acta 64, 233-246.

Algeo, T. J., Luo G. M., Song, H. Y., Lyons T. W. and Canfield D. E. (2015) Reconstruction of secular variation in seawater sulfate concentrations. Biogeosciences 12, 2131-2151.

Balci N., Shanks W. C., III, Mayer B. and Mandernack K. W. (2007) Oxygen and sulfur isotope systematics of sulfate produced by bacterial and abiotic oxidation of pyrite. Geochim. Cosomochim. Acta 71, 3796-3811.

Basuki N. I. and Spooner E. T. C. (2002) A review of fluid inclusion temperatures and salinities in Mississippi Valley-type $\mathrm{Zn}-\mathrm{Pb}$ deposits, identifying thresholds for metal transport. Explor. Min. Geol. 11, 1-17, doi:10.2113/11.1-4.1.

Bethke C. M. (1986) Hydrologic constraints on the genesis of the Upper Mississippi Valley Mineral District from Illinois Basin brines. Econ. Geol. 81, 233-249.

Boschetti T. (2013) Oxygen isotope equilibrium in sulfate-water systems: a revision of geothermometric applications in low-enthalpy systems. J. Geochem. Explor. 124, 92-100.

Böttcher M., Thamdrup B., Gehre M. and Theune A. (2005) ${ }^{34} \mathrm{~S} /{ }^{32} \mathrm{~S}$ and ${ }^{18} \mathrm{O}{ }^{16} \mathrm{O}$ fractionation during sulfur disproportionation by Desulfobulbus propionicus. Geomicrobiol. J. 22, 219-226.

Bottrell S. H. and Newton R. J. (2006) Reconstruction of changes in global sulfur cycling from marine sulfate isotopes. Earth-Sci. Rev. 75, 59-83.

Brennan S.T., Lowenstein T.K., and Horita J. (2004) Seawater chemistry and the advent of biocalcification. Geology, 32, 473-476.

Brunner B., Bernasconi S. M., Kleikemper J. and Schroth M. (2005) A model for oxygen and sulfur isotope fractionation in sulfate during bacterial sulfate reduction processes. Geochim. Cosmochim. Acta 69, 4773-4785. 
Burdett J. W., Arthur M. A. and Richardson M. (1989) A Neogene seawater sulfur isotope age curve from calcareous pelagic microfossils. Earth Planet. Sci. Lett. 94, 189-198.

Buschbach T. C. (1975) Cambrian System. In Handbook of Illinois Stratigraphy (eds. H. B. Willman, T. C. Buschbach, C. Collinson, J. C. Frye, M. E. Hopkins, J. A. Lineback and J. A. Simon). Ill. State Geol. Surv., Bull. 95, 46 pp.

Came R. E., Eiler J. M., Veizer J., Azmy K., Brand U. and Weidman C. R. (2007) Coupling of surface temperatures and atmospheric $\mathrm{CO}_{2}$ concentrations during the Paleozoic era. Nature 449, $198-201$.

Chiba H. and Sakai H. (1985) Oxygen isotope exchange rate between dissolved sulfate and water at hydrothermal temperatures. Geochim. Cosomochim. Acta 49, 993-1000.

Claypool G. E., Holser W. T., Kaplan I. R., Sakai H. and Zak I. (1980) The age curves of sulfur and oxygen isotopes in marine sulfate and their mutual interpretation. Chem. Geol. 28, 199-260.

Cohen K. M., Finney S. C., Gibbard P. L. and Fan J.-X. (2013) The ICS International Chronostratigraphic Chart. Episodes 36, 199-204.

Cortecci G. and Longinelli A. (1971) ${ }^{18} \mathrm{O} /{ }^{16} \mathrm{O}$ ratios in sulfate from living marine organisms. Earth Planet. Sci. Lett. 11, 273-276.

Dong Y., Kumar C. G., Chia N., Kim P.-J., Miller P. A., Price N. D., Cann I. K. O., Flynn T. M., Sanford, R. A., Krapac I. G., Locke R. A., II, Hong P.-Y., Tamaki H., Liu W.-T., Mackie R. I., Hernandez A. G., Wright C. L., Mikel M. A., Walker J. L., Sivaguru M., Fried G., Yannarell A. C. and Fouke B. W. (2013) Halomonas sulfidaeris-dominated microbial community inhabits a 1.8 kmdeep subsurface Cambrian Sandstone reservoir. Environ. Microbiol. 16, 1695-1708, doi:10.111/1462-2920.12325.

Droste J. B. and Patton J. B. (1985) Lithostratigraphy of the Sauk Sequence in Indiana. Indiana Geol. Surv., Occas. Paper 47, 24 pp.

Ervin C. P. and McGinnis L. D. (1975) Reelfoot Rift: reactivated precursor to the Mississippi Embayment. Geol. Soc. Am. Bull. 86, 1287-1295. 
Emich G. H. (1966) Ironton and Galesville (Cambrian) Sandstones in Illinois and adjacent areas. Ill. State Geol. Surv., Circ. 403, 55 pp.

Faure G. and Mensing T. M. (2005) Isotopes: Principles and Applications, third ed. John Wiley \& Sons, Hoboken, NJ.

Freiburg J. T., Morse D. G., Leetaru H. E., Hoss R. P. and Yan Q. (2014) A depositional and diagenetic characterization of the Mt. Simon Sandstone at the Illinois Basin-Decatur Project carbon capture and storage site, Decatur, Illinois, USA. Ill. State Geol. Surv., Circ. 583, 42 pp.

Gerdemann P. E. and Myers H. E. (1972) Relationships of carbonate facies patterns to ore distribution and to ore genesis in Southeast Missouri lead district. Econ. Geol. 67, 426-433, doiL10.2113/gsecongeo.67.4.426.

Gilkeson R. H., Perry E. C., Jr. and Cartwright K. (1981) Isotopic and Geologic Studies to Identify the Sources of Sulfate in Groundwater Containing High Barium Concentrations. Univ. Ill. UrbanaChampaign, Water Resour. Cent. Res. Rep., Project No. A-100-I11.

Gill B. C., Lyons T. W. and Saltzman M. (2007) Parallel, high-resolution carbon and sulfur isotope records of the evolving Paleozoic marine sulfur reservoir. Palaeogeogr. Palaeocl. 256, 156-173.

Gill B. C., Lyons T. W. and Frank T. D. (2008) Behavior of carbonate-associated sulfate during meteoric diagenesis and implications for the sulfur isotope paleoproxy. Geochim. Cosmochim. Acta 72, $4699-4711$.

Gill B. C., Lyons T., Young S. A., Kump L. R., Knoll A. H. and Saltzman M. (2011) Geochemical evidence for widespread euxinia in the later Cambrian ocean. Nature 469, 80-83, doi:10.1038/nature09700.

Goldhaber M. B. (2004) Sulfur geochemistry of Paleozoic rocks, U.S. mid-continent: implications for large-scale fluid flow and ore genesis. In Water-Rock Interaction, vol. 1 (eds. R. B. Wanty and R. R. Seal). Taylor \& Francis Group, London, pp. 273-276.

Gregg J. M. (1985) Regional epigenetic dolomitization in the Bonneterre Dolomite (Cambrian), southeastern Missouri. Geology 13, 503-506. 
Gregg J. M. (1988) Origins of dolomite in the offshore facies of the Bonneterre Formation (Cambrian), southeast Missouri. In Sedimentology and Geochemistry of Dolostones. SEPM Spec. Publ. 43, pp. 67-83.

Gregg J. M. and Shelton K. L. (2012) Mississippi Valley-type mineralization and ore deposits in the Cambrian-Ordovician Great American Carbonate Bank. In The Great American Carbonate Bank: The Geology and Economic Resources of the Cambrian-Ordovician Sauk Megasequence of Laurentia (eds. J. R. Derby, R. D. Fritz, S. A. Longacre, W. A. Morgan and C. A. Stembach). AAPG Mem. 98, pp. 161-185.

Halas S. and Pluta I. (2000) Empirical calibration of isotope thermometer $\delta^{18} \mathrm{O}\left(\mathrm{SO}_{4}{ }^{2-}\right)-\delta^{18} \mathrm{O}\left(\mathrm{H}_{2} \mathrm{O}\right)$ for low temperature brines. In Proceedings V Isotope Workshop. Eur. Soc. Isot. Res., Kraków, Poland, pp. 68-71.

Heidel C. and Tichomirowa M. (2011) The isotopic composition of sulfate from anaerobic and low oxygen pyrite oxidation experiments with ferric iron—new insights into oxidation mechanisms. Chem. Geol. 281, 305-316.

Holser W. T. and Kaplan I. R. (1966) Isotope geochemistry of sedimentary sulfates. Chem. Geol. 1, $93-135$.

Holser W. T., Schidlowski M., Mackenzie F. T. and Maynard J. B. (1988) Biogeochemical cycles of carbon and sulfur. In Chemical Cycles in the Evolution of Earth (eds. C. B. Gregor, R. M. Garrels, F. T. Mackenzie and J.B. Maynard). Wiley-Interscience, New York, pp. 105-174.

Horita J., Cole D. R. and Wesolowski D. J. (1993a) The activity-composition relationship of oxygen and hydrogen isotopes in aqueous salt solutions: I. Vapor-liquid water equilibration of single salt solutions from 50 to $100{ }^{\circ}$ C. Geochim. Cosmochim. Acta 57, 2797-2817.

Horita J., Cole D. R. and Wesolowski D. J. (1993b) The activity composition relationship of oxygen and hydrogen isotopes in aqueous salt solutions: II. Vapor-liquid water equilibration of mixed salt 
solutions from 50 to $100{ }^{\circ} \mathrm{C}$ and geochemical implications. Geochim. Cosmochim. Acta 57, 47034711.

Horita J., Cole D. R. and Wesolowski D. J. (1994) Salt effects on stable isotope partitioning and their geochemical implications for geothermal brines. In Proceedings: Nineteenth Workshop on Geothermal Reservoir Engineering, January 18-20, 1994. Stanford Univ., Stanford Geotherm. Progr. Workshop Rep. SGP-TR-147, pp. 285-290.

Hough M. L., Shields G. A., Evins L. Z., Strauss H., Henderson R. A. and Mackenzie S. (2006) A major sulphur isotope event at c. $510 \mathrm{Ma}$ : a possible anoxia-extinction-volcanism connection during the Early-Middle Cambrian transition. Terra Nova 18, 257-263.

Houseknecht D.W. and Ethridge F.G. (1978) Depositional history of the Lamotte Sandstone of southeastern Missouri. J. Sediment. Petrol. 48, 575-586.

Hyodo A., Kozdon R., Pollington A. D. and Valley J. W. (2014) Evolution of quartz cementation and burial history of the Eau Claire Formation based on in situ oxygen isotope analysis of quartz overgrowths. Chem. Geol. 384, 168-180.

Jaffrés J. B. D., Shields G. A. and Wallmann K. (2007) The oxygen isotope evolution of seawater: A critical review of a long-standing controversy and an improved geological water cycle model for the past 3.4 billion years. Earth Sci. Rev. 83, 83-122.

John E. H., Wignall P. B., Newton R. J. and Bottrell S. H. (2010) $\delta^{34} \mathrm{~S}_{\mathrm{CAS}}$ and $\delta^{18} \mathrm{O}_{\mathrm{CAS}}$ records during the Frasnian-Famennian (Late Devonian) transition and their bearing on mass extinction models. Chem. Geol. 275, 221-234.

Kampschulte A. and Strauss H. (2004) The sulfur isotopic evolution of Phanerozoic seawater based on the analysis of structurally substituted sulfate in carbonates. Chem. Geol. 204, 255-286.

Kesler S. E., Venneman T. W., Frederickson C., Breithaupt A., Vazquez R. and Furman F. C. (1997) Hydrogen and oxygen isotope evidence for origin of MVT-forming brines, southern Appalachians. Geochim. Cosmochim. Acta 61, 1513-1523. 
Kolata, D. R. (2010) Cambrian and Ordovician Systems (Sauk Sequence and Tippecanoe I Subsequence). In Geology of Illinois (ed. D. R. Kolata and C. K. Nimz). Ill. State Geol. Surv., Champaign, pp. $136-157$.

Kolata D. R. and Nelson W. J. (2010). Tectonic history. In Geology of Illinois (eds. D. R. Kolata and C. K. Nimz). Ill. State Geol. Surv., Champaign, pp. 77-89.

Kusakabe M. and Robinson W. (1977) Oxygen and sulfur isotope equilibria in the $\mathrm{BaSO}_{4}-\mathrm{HSO}_{4}^{-}-\mathrm{H}_{2} \mathrm{O}$ system from 110 to $350^{\circ} \mathrm{C}$ with applications. Geochim. Cosmochim. Acta 41, 11033-11040.

Labotka D. M., Panno S. V., Locke R. A., III and Freiburg J. T. (2015) Isotopic and geochemical characterization of fossil brines of the Cambrian Mt. Simon Sandstone and Ironton-Galesville Formation from the Illinois Basin, USA. Geochim. Cosmochim. Acta 165, 342-360.

Larson D. R. and Herzog B. L. (2004) Aquifers. In Geology of Illinois (eds. D. R. Kolata and C. K Nimz). Ill. State Geol. Surv., Champaign, pp. 325-336.

Leach D. L., Taylor R. D., Fey D. L., Diehl S. F. and Saltus R. W. (2010) A deposit model for Mississippi Valley type lead-zinc ores. U.S. Geol. Surv., Sci. Investig. Rep. 2010-5070-A, 51 pp.

Lloyd R. M. (1968) Oxygen isotope behavior in the sulfate-water system. J. Geophys. Res. 73, 6099-6110.

Locke R., II, Larssen D., Salden W., Patterson C., Kirksey J., Iranmanesh A., Wimmer B. and Krapac I. (2013) Preinjection reservoir fluid characterization at a CCS demonstration site: Illinois BasinDecatur Project, USA. Energy Procedia 37, 6424-6433.

Lohmann K. C. and Walker J. C. G. (1989) The $\delta^{18}$ O record of Phanerozoic abiotic marine calcite cements. Geophys. Res. Lett. 16, 319-322.

Lyons T. W., Walter L. M., Gellatly A. M., Martini A. M. and Blake R. E. (2004) Sites of anomalous organic remineralization in the carbonate sediments of South Florida, USA: the sulfur cycle and carbonate-associated sulfate. In Sulfur Biogeochemistry—Past and Present (eds. J. P. Amend, K. E. Edwards and T. W. Lyons). Geol. Soc. Am., Spec. Pap. 379, pp. 161-176. 
McKay, R. M. (1988) Stratigraphy and lithofacies of the Dresbachian (Upper Cambrian) Eau Claire Formation in the subsurface of eastern Iowa. In New Perspectives on the Paleozoic History of the Upper Mississippi Valley (eds. G. A. Ludvigson and B. J. Bunker). Iowa Dep. Nat. Resour., Geol. Surv., Guideb. 8, pp. 33-53.

Mizutani Y. and Rafter T. A. (1973) Isotopic behavior of sulphate oxygen in bacterial reduction of sulphate. Geochem. J. 6, 183-191.

Neufelder R. J., Bowen B. B., Lahann R. W. and Rupp J. A. (2012) Lithologic, mineralogic, and petrophysical characteristics of the Eau Claire Formation: complexities of a carbon storage system seal. Environ. Geosci. 19, 81-104.

Newton J. J., Pevitt E. L., Wignall P. B. and Bottrell S. H. (2004) Large shifts in the isotopic composition of seawater sulphate across the Permo-Triassic boundary in northern Italy. Earth Planet. Sci. Lett. 218, 331-345.

Ojakangas R. W. (1963) Petrology and sedimentation of the Upper Cambrian Lamotte Sandstone in Missouri. J. Sediment. Petrol. 33, 860-873.

Palmer A. R. (1981) Subdivision of the Sauk Sequence. In Short Papers for the Second International Symposium on the Cambrian System (ed. M. E. Taylor). U.S. Geol. Surv., Open-File Rep. 81743, pp. 160-162.

Panno S. V., Harbottle G. and Sayre E. V. (1988) Distribution of selected elements in the shale of the Davis Formation, Buick Mine area, Viburnum Trend, southeast Missouri. Econ. Geol. 83, 140152.

Panno S. V., Hackley K. C., Randall A. L., Krapac I. G., Wimmer B., Iranmanesh A. and Kelly W. R. (2013) Formation waters from Cambrian-age strata, Illinois Basin, USA: Constraints on their origin and evolution. Geochim. Cosmochim. Acta 122, 184-197.

Pollington A. D., Kozdon R. and Valley J. W. (2011) Evolution of quartz cementation in the Illinois Basin during burial of the Mt. Simon Sandstone: in situ microanalysis of the $\delta^{18} \mathrm{O}$. Geology 39, 1119-1122. 
Present T. M., Paris G., Burke A., Fischer W. W. and Adkins J. F. (2015) Large carbonate associated sulfate isotopic variability between brachiopods, micrite, and other sedimentary components in Late Ordovician strata. Earth. Planet. Sci. Lett. 432, 187-198.

Rennie V. C. F. and Turchyn A. V. (2014) The preservation of $\delta^{34} \mathrm{~S}_{\mathrm{SO} 4}$ and $\delta^{18} \mathrm{O}_{\mathrm{SO} 4}$ in carbonateassociated sulfate during marine diagenesis: A 25 Myr test case using marine sediments. Earth. Planet. Sci. Lett. 395, 13-23.

Rogers K. R. and Davis J. H. (1977) Geology of the Buick Mine, Viburnum Trend, southeast Missouri. Econ. Geol. 72, 372-380.

Rowan E. L. and Goldhaber M. B. (1995) Regional fluid flow as a factor in the thermal history of the Illinois Basin: constraints from fluid inclusions and the maturity of Pennsylvanian coals. Am. Assoc. Pet. Geol., Bull. 86, pp. 257-277.

Runkel A. C., McKay R. M., Cowan C. A., Miller J. F. and Taylor J. F. (2012) The Sauk megasequence in the cratonic interior of North America: interplay between a fully developed inner detrital belt and the central great American carbonate bank. In The Great American Carbonate Bank: The Geology and Economic Resources of the Cambrian-Ordovician Sauk Megasequence of Laurentia (eds. J. R. Derby, R. D. Fritz, S. A. Longacre, W. A. Morgan and C. A. Sternbach,). AAPG Mem. 98, 1001-1011.

Sakai H. and Krouse H. R. (1971) Elimination of memory effects in ${ }^{18} \mathrm{O} /{ }^{16} \mathrm{O}$ determination in sulphates. Earth Planet. Sci. Lett. 11, 369-373.

Saltzman M. R., Cowan C. A., Runkel R. C., Runnegar B., Stewart M. C. and Palmer A. R. (2004) The Late Cambrian SPICE $\left(\delta^{13} \mathrm{C}\right)$ event and the Sauk II-Sauk III regression: new evidence from Laurentian basins in Utah, Iowa, and Newfoundland. J. Sediment. Res. 74, 366-377.

Sargent M. L. (1991) Sauk Sequence: Cambrian System through Lower Ordovician Series. In Interior Cratonic Basins (eds. M. W. Leighton, D. R. Kolata, D. F. Oltz and J. J. Eidel). AAPG Mem. 51, pp. $75-86$. 
Seal R. R., II (2006) Sulfur isotope geochemistry of sulfide minerals. Rev. Mineral. Geochem. 61, 633677.

Seal R. R., II, Alpers C. N. and Rye R. O. (2000) Stable isotope systematics of sulfate minerals. In Sulfate Minerals: Crystallography, Geochemistry, and Environmental Significance (eds. J. L. Jambor and D. K. Nordstrom). Mineral. Soc. Am. and Geochem. Soc., Rev. Mineral. Geochem. 40, pp. 541602.

Schröder S., Schreiber B. C., Amthor J. E. and Matter A. (2004) Stratigraphy and environmental conditions of the terminal Neoproterozoic-Cambrian Period in Oman: evidence from sulphur isotopes. J. Geol. Soc. 161, 489-499.

Scotese C. R. and McKerrow W. S. (1990) Revised world maps and introduction. In Palaeozoic Palaeogeography and Biogeography (eds. W. S. McKerrow and C. R. Scotese). Geol. Soc. Lond., Mem. 12, pp. 1-21.

Shaw T. H. and Sargent M. L. (1989) Catalog of cores from the sub-Galena Group in Illinois. Illinois Pet. 132, $30 \mathrm{pp}$.

Shelton K. L., Gregg J. M. and Johnson A. W. (2009) Replacement dolomites and ore sulfides as recorders of multiple fluids and fluid sources in southeast Missouri MVT district, U.S.A.: Halogen- ${ }^{87} \mathrm{Sr} /{ }^{86} \mathrm{Sr}-\delta^{18} \mathrm{O}-\delta^{34} \mathrm{~S}$ systematics in Bonneterre Dolomite. Econ. Geol. 104, 733-748, doi:10.2113/gsecongeo.104.5.733.

Siegel D. I. (1989) Geochemistry of the Cambrian-Ordovician aquifer system in the northern Midwest, United States. U.S. Geol. Surv., Prof. Pap. 1405-D, 76 pp.

Siegel D. I. (1990). Sulfur isotope evidence for regional recharge of saline water during continental glaciation, north-central United States. Geology 18, 1054-1056.

Siegel D. I. and Mandle R. J. (1984) Isotopic evidence for glacial meltwater recharge to the CambrianOrdovician aquifer, north-central United States. Quat. Res. 22, 328-335. 
Snyder F. G. and Gerdemann P. E. (1968) Geology of the southeast Missouri lead district. In Ore Deposits of the United States, 1933-1967 (Graton-Sales volume, ed. J. D. Ridge). Am. Inst. Min., Metall. Pet. Eng. 1, pp. 326-358.

Stevenson D. L., Chamberlin T. L. and Buschbach T. C. (1975) Insoluble residues of the Sauk Sequence (Cambrian and Lower Ordovician) rocks of the Fairfield Basin, Illinois: an aid in correlation and in petroleum exploration. Ill. State Geol. Surv., Illinois Pet. 106, 12 pp.

Sverjensky D. A. (1981) The origin of a Mississippi Valley-type deposit in the Viburnum Trend, southeast Missouri. Econ. Geol. 76, 1848-1872.

Thode H. G. and Monster J. (1965) Sulfur-isotope geochemistry of petroleum, evaporites, and ancient seas. Am. Assoc. Petrol. Geol., Mem. 4, pp. 367-377.

Thompson T. L. (1995) The stratigraphic succession in Missouri. Mo. Dep. Nat. Resour., Div. Geol. Land Surv. 40, 190 pp.

Thompson T. L. (2001) Lexicon of stratigraphic nomenclature in Missouri. Mo. Dep. Nat. Resour., Div. Geol. Land Surv., Rep. Investig. 73, 371 pp.

Treworgy J. D., Whitaker S. T. and Lasemi Z. (1997) Structural cross section of the Paleozoic rocks in Illinois, Wayne County to Stephenson County. Ill. State Geol. Surv., Illinois Map 7, 2 sheets.

Turchyn A. V. and Schrag D. P. (2004) Oxygen isotope constraints on the sulfur cycle over the past 10 million years. Science 303, 2004-2007.

Turchyn A. V. and Schrag D. P. (2006) Cenozoic evolution of the sulfur cycle: insight from oxygen isotopes in marine sulfate. Earth Planet. Sci. Lett. 241, 763-779.

Turchyn A. V., Sivan O. and Schrag D. P. (2006) Oxygen isotopic composition of sulfate in deep sea pore fluid: evidence for rapid sulfur cycling. Geobiology, 4, 191-201.

Turchyn A. V., Brüchert V., Lyons T. W., Engel G. S. N., Schrag D. P. and Brunner B. (2010) Kinetic oxygen isotope effects during dissimilatory sulfate reductions: a combined theoretical and experimental approach. Geochim. Cosmochim. Acta 74, 2011-2024. 
Ueda A. and H. R. Krouse (1986) Direct conversion of sulphide and sulphate minerals to $\mathrm{SO}_{2}$ for isotope analyses. Geochem. J. 20, 209-212.

van Stempvoort D. R. and Krouse H. R. (1994) Controls of $\delta^{18} \mathrm{O}$ in sulfate: a review of experimental data application to specific environments. In Environmental Geochemistry of Sulfide Oxidation (eds. C. A. Alpers and D. W. Blowes). Am. Chem. Soc., Washington, DC, pp. 446-480.

Walter L. M., Stueber A. M. and Huston T. J. (1990) Br-Cl-Na systematics in Illinois basin fluids: constraints on fluid origin and evolution. Geology 18, 315-318.

Wang X.-B., Nicholas J. B. and Wang L. S. (2000) Electronic instability of isolated $\mathrm{SO}_{4}{ }^{2-}$ and its solvation stabilization. J. Chem. Phys. 113, 10837-10840.

Wankel S. D., Bradley A. S., Eldridge D. L. and Johnston D. T. (2014) Determination and application of the equilibrium oxygen isotope effect between water and sulfite. Geochim. Cosmochim. Acta 125, 694-711.

Wilson J. L. and Jordan C. (1983) Middle-shelf environment. In Carbonate Depositional Environments (eds. P. A. Scholle, D. G. Bebout and C. H. Moore). AAPG Mem. 33, pp. 298-343.

Wong R. L. and Williams E. R. (2003) Dissociation of $\mathrm{SO}_{4}{ }^{2-}\left(\mathrm{H}_{2} \mathrm{O}\right)_{n}$ clusters, $n=3-17$. J. Chem. Phys. A 107, 10976-10983.

Workman L. E. and Bell A. H. (1948) Deep drilling and deeper oil possibilities in Illinois. AAPG Bull. 32, $2041-2062$.

Wortmann U. G., Chernyavsky B., Bernasconi S. M., Brunner B., Böttcher M. E. and Swart P. K. (2007) Oxygen isotope biogeochemistry of pore water sulfate in the deep biosphere: dominance of isotope exchange reactions with ambient water during microbial sulfate reduction (ODP Site 1130). Geochim. Cosmochim. Acta 71, 4221-4232.

Yanagisawa F. and Sakai H. (1983) Thermal decomposition of barium sulfate-vanadium pentaoxide-silica glass mixture for preparation of sulfur dioxide in sulfur isotope ratio measurements. Anal. Chem. 55, 985-987, doi:10.1021/ac00257a046. 
Zak I., Sakai H. and Kaplan I. R. (1980) Factors controlling the ${ }^{18} \mathrm{O} /{ }^{16} \mathrm{O}$ and ${ }^{34} \mathrm{~S} /{ }^{32} \mathrm{~S}$ isotope ratios of ocean sulfates in modern deep sea sediments. In Isotope Marine Chemistry (eds. E.D. Goldberg, Y. Horbie, and K. Saruhashi). Geochem. Res. Assoc., Tokyo, pp. 339-373.

Zeebe R. E. (2010). A new value for the stable oxygen isotope fractionation between dissolved sulfate ion and water. Geochim. Cosmochim. Acta 74, 818-828.

Zhou J., Santambrogio G., Brümmer M., Moore D. T., Wöste L., Meijer G., Neumark D. M. and Asmis K. R. (2006) Infrared spectroscopy of hydrated sulfate dianions. J. Chem. Phys. 125, 111102. 


\section{Figures:}

Fig. 1. Location of VW1 and Eau Claire and Bonneterre Formation dolomite samples (stars) and the Old Lead Belt and Viburnum Trend ore deposits in relation to the depositional environment of the Illinois Basin in Laurentia during the Late Cambrian.

Fig. 2. Generalized stratigraphic column showing the relationship between the core sample sites from southwestern Illinois and southeastern Missouri (EC-8948, EC-8949, and Buick Mine) compiled from Kolata (2010), Runkel et al. (2012), and Thompson (2001) and VW1 core from Decatur, Illinois, compiled from Freiburg et al. (2014). Stage and sequence designations were defined by trilobite assemblages in the Eau Claire and Bonneterre Formations (McKay, 1988; Thompson, 1995).

Fig. 3. The $\delta^{34} \mathrm{~S}_{\mathrm{SO} 4}$ and $\mathrm{SO}_{4}$ concentration of dissolved sulfate in the Cambrian-hosted brines of the Mt. Simon Sandstone and Ironton-Galesville Sandstone along an in-depth profile of geology. Dashed lines represent the $\delta^{34} \mathrm{~S}_{\mathrm{SO} 4}$ isotope range from $30 \%$ o to $39 \%$ capturing the brine $\delta^{34} \mathrm{~S}_{\mathrm{SO} 4}$ values within Cambrian seawater sulfate values.

Fig. 4. Sulfate-water oxygen isotope fractionation compared with zone temperature measured in the Mt. Simon and Ironton-Galesville. The isotope data were corrected for the salt effect as described in the text. The theoretical equation for the sulfate-water isotope equilibrium line is calculated from Zeebe (2010), and the empirical equation is calculated from Halas and Pluta (2000). Individual zones are labeled. 
Fig. 5. Sulfate isotope comparison of dissolved sulfate in the Cambrian rock-hosted brines and CAS of the Eau Claire and Bonneterre Formations. Estimated seawater sulfate isotope values of Cambrian seawater and Late Pennsylvanian-Early Permian seawater (Claypool et al., 1980;

Kampschulte and Strauss, 2004) are documented for comparison. The shaded gray box denotes the reported range of $\delta^{34} \mathrm{~S}$ values of MVT sulfides (Sverjensky, 1981; Leach et al., 2010) and the reported range for $\delta^{18} \mathrm{O}$ values of sulfate resulting from the oxidation of pyrite in marine settings (Turchyn and Schrag, 2004). 
Table 1

Physical and chemical characteristics of Cambrian brines (concentrations in $\mathrm{mg} / \mathrm{L}$ ). ${ }^{\mathrm{a}, \mathrm{b}, \mathrm{c}, \mathrm{d}, \mathrm{e}, \mathrm{f}}$

\begin{tabular}{|c|c|c|c|c|c|c|c|c|c|c|c|c|c|c|c|}
\hline Zone & $\begin{array}{l}\text { Depth } \\
\text { (m) }\end{array}$ & $\begin{array}{l}\text { Temp } \\
\left({ }^{\circ} \mathrm{C}\right)\end{array}$ & $\begin{array}{l}\text { Density } \\
\left(\mathrm{g} / \mathrm{cm}^{3}\right)\end{array}$ & $\begin{array}{c}\mathrm{pH} \\
\text { units }\end{array}$ & $\begin{array}{c}\delta^{18} \mathrm{O}(\%) \\
\text { comp. } \\
(\mathrm{V}- \\
\text { SMOW) }\end{array}$ & $\begin{array}{c}\delta^{18} \mathrm{O} \\
(\% o) \\
\text { activity }^{\mathrm{d}}\end{array}$ & $\begin{array}{c}\delta \mathrm{D}(\%) \\
\text { comp. } \\
(\mathrm{V}- \\
\text { SMOW) }\end{array}$ & $\begin{array}{l}\delta \mathrm{D}(\%) \\
\text { activity }^{\mathrm{d}}\end{array}$ & $n$ & $\begin{array}{c}\delta^{18} \mathrm{O}(\%) \\
\left(\mathrm{SO}_{4}\right)(\mathrm{V}- \\
\mathrm{SMOW})\end{array}$ & $\begin{array}{c}\delta^{34} \mathrm{~S}(\%) \\
\left(\mathrm{SO}_{4}\right) \\
(\mathrm{V}-\mathrm{CDT})\end{array}$ & $n$ & $\begin{array}{l}\text { Zeebe } \\
(2010)^{\mathrm{e}}\end{array}$ & $\begin{array}{l}\text { Halas } \\
\text { and } \\
\text { Pluta } \\
(2000)^{\mathrm{f}}\end{array}$ & $\begin{array}{l}\Delta^{18} \mathrm{O} \\
\text { activity- } \\
\text { sulfate }\end{array}$ \\
\hline 11 & 1,490 & 43 & 1.043 & 6.9 & $\begin{array}{c}-7.4 \\
( \pm 0.27)\end{array}$ & -7.6 & $\begin{array}{c}-56 \\
( \pm 0.7)\end{array}$ & -50 & 3 & $\begin{array}{c}13.1 \\
( \pm 0.15)\end{array}$ & $\begin{array}{c}22.8 \\
( \pm 0.15)\end{array}$ & 3 & 19.5 & 18.5 & 20.7 \\
\hline 10 & 1,515 & 44 & 1.046 & 6.9 & $\begin{array}{c}-6.9 \\
( \pm 0.21)\end{array}$ & -7.2 & $\begin{array}{c}-52 \\
( \pm 0.8)\end{array}$ & -48 & 3 & $\begin{array}{c}12.9 \\
( \pm 0.05)\end{array}$ & $\begin{array}{c}22.6 \\
( \pm 0.12)\end{array}$ & 3 & 19.4 & 18.3 & 20.0 \\
\hline 9 & 1,714 & 46 & 1.101 & 6.3 & $\begin{array}{c}-4.9 \\
( \pm 0.40)\end{array}$ & -5.5 & $\begin{array}{c}-32 \\
( \pm 1.5)\end{array}$ & -20 & 3 & $\begin{array}{c}14.8 \\
( \pm 0.25)\end{array}$ & $\begin{array}{c}33.2 \\
( \pm 0.20)\end{array}$ & 3 & 19.0 & 18.0 & 20.2 \\
\hline 8 & 1,770 & 48 & 1.110 & 6.4 & $\begin{array}{c}-5.0 \\
( \pm 0.36)\end{array}$ & -5.6 & $\begin{array}{c}-34 \\
( \pm 1.6)\end{array}$ & -21 & 3 & $\begin{array}{c}15.4 \\
( \pm 0.28)\end{array}$ & $\begin{array}{c}39.0 \\
( \pm 0.00)\end{array}$ & 3 & 18.7 & 17.7 & 21.1 \\
\hline 7 & 1,944 & 50 & 1.136 & 5.8 & $\begin{array}{c}-3.8 \\
( \pm 0.57)\end{array}$ & -4.7 & $\begin{array}{c}-25 \\
( \pm 1.1)\end{array}$ & -10 & 4 & $\begin{array}{c}13.1 \\
( \pm 0.47)\end{array}$ & $\begin{array}{c}37.9 \\
( \pm 0.06)\end{array}$ & 3 & 18.4 & 17.5 & 17.8 \\
\hline 6 & 2,010 & 51 & 1.138 & 6.4 & $\begin{array}{c}-3.6 \\
( \pm 0.65)\end{array}$ & -4.5 & $\begin{array}{c}-25 \\
( \pm 3.0)\end{array}$ & -9 & 4 & $\begin{array}{c}14.2 \\
( \pm 0.41)\end{array}$ & $\begin{array}{c}35.2 \\
( \pm 0.31)\end{array}$ & 3 & 18.2 & 17.3 & 18.7 \\
\hline 5 & 2,036 & 48 & 1.137 & 6.4 & $\begin{array}{c}-2.9 \\
( \pm 0.36)\end{array}$ & -3.7 & $\begin{array}{c}-23 \\
( \pm 1.7)\end{array}$ & -7 & 5 & $\begin{array}{c}14.1 \\
( \pm 0.45)\end{array}$ & $\begin{array}{c}34.2 \\
( \pm 0.00)\end{array}$ & 3 & 18.7 & 17.7 & 17.8 \\
\hline 4 & 2,072 & 48 & 1.141 & 6.3 & $\begin{array}{c}-2.8 \\
( \pm 0.25)\end{array}$ & -3.7 & $\begin{array}{c}-22 \\
( \pm 1.4)\end{array}$ & -6 & 4 & $\begin{array}{c}14.8 \\
( \pm 0.09)\end{array}$ & $\begin{array}{c}35.4 \\
( \pm 0.06)\end{array}$ & 3 & 18.7 & 17.7 & 18.5 \\
\hline 3 & 2,105 & 50 & 1.139 & 6.4 & $\begin{array}{c}-2.9 \\
( \pm 0.16)\end{array}$ & -3.8 & $\begin{array}{c}-23 \\
( \pm 0.6)\end{array}$ & -6 & 4 & $\begin{array}{c}14.9 \\
( \pm 0.29)\end{array}$ & $\begin{array}{c}34.5 \\
( \pm 0.06)\end{array}$ & 3 & 18.4 & 17.5 & 18.7 \\
\hline 2 & 2,116 & 50 & 1.138 & 6.8 & $\begin{array}{c}-3.0 \\
( \pm 0.26)\end{array}$ & -3.8 & $\begin{array}{c}-24 \\
( \pm 1.6)\end{array}$ & -8 & 3 & $\begin{array}{c}15.1 \\
( \pm 0.29)\end{array}$ & $\begin{array}{c}33.9 \\
( \pm 0.06)\end{array}$ & 3 & 18.4 & 17.5 & 18.9 \\
\hline
\end{tabular}


Table 1 (continued).

\begin{tabular}{|c|c|c|c|c|c|c|c|c|}
\hline $\mathrm{Ca}^{2+}$ & $\mathrm{Mg}^{2+}$ & $\mathrm{Sr}^{++}$ & $\mathrm{Na}^{+}$ & $\mathrm{K}^{+}$ & $\mathrm{Cl}^{-}$ & $\mathrm{SO}_{4}{ }^{2-}$ & TDS & $n$ \\
\hline $5,135( \pm 0)$ & $948( \pm 20)$ & $134( \pm 5)$ & $16,465( \pm 105)$ & $502( \pm 19)$ & $36,084( \pm 794)$ & $1,234( \pm 14)$ & 63,645 & 2 \\
\hline $5,375( \pm 87)$ & $942( \pm 5)$ & $138( \pm 4)$ & $17,918( \pm 108)$ & $577( \pm 18)$ & $39,378( \pm 778)$ & $1,185( \pm 48)$ & 68,895 & 2 \\
\hline $13,379( \pm 29)$ & $1,943( \pm 11)$ & $379( \pm 11)$ & $37,614( \pm 296)$ & $1,687( \pm 1)$ & $88,776( \pm 1,816)$ & $917( \pm 14)$ & 150,840 & 2 \\
\hline $15,785( \pm 85)$ & $2,101( \pm 10)$ & $500( \pm 13)$ & $39,526( \pm 214)$ & $1,641( \pm 0)$ & $96,849( \pm 2,239)$ & $643( \pm 13)$ & 172,870 & 2 \\
\hline $21,186( \pm 812)$ & $2,273( \pm 80)$ & $772( \pm 24)$ & $46,990( \pm 1,460)$ & $2,227( \pm 75)$ & $119,527( \pm 2,446)$ & $254( \pm 78)$ & 203,760 & 3 \\
\hline $21,787( \pm 682)$ & $2,359( \pm 82)$ & $789( \pm 30)$ & $48,036( \pm 1,777)$ & $2,201( \pm 88)$ & $120,457( \pm 2,735)$ & $312( \pm 27)$ & 205,275 & 3 \\
\hline $20,400( \pm 1,295)$ & $2,860( \pm 133)$ & $753( \pm 49)$ & $47,434( \pm 2,908)$ & $2,085( \pm 110)$ & $118,460( \pm 2,103)$ & $323( \pm 14)$ & 202,980 & 5 \\
\hline $21,583( \pm 244)$ & $2,311( \pm 71)$ & $786( \pm 22)$ & $48,500( \pm 1,757)$ & $2,110( \pm 23)$ & $121,025( \pm 918)$ & $325( \pm 1)$ & 205,525 & 4 \\
\hline $22,240( \pm 270)$ & $2,370( \pm 33)$ & $813( \pm 9)$ & $49,583( \pm 397)$ & $2,083( \pm 14)$ & $119,975( \pm 411)$ & $376( \pm 1)$ & 207,300 & 4 \\
\hline $20,953( \pm 1,586)$ & $2,255( \pm 170)$ & $758( \pm 54)$ & $48,043( \pm 3,477)$ & $2,068( \pm 9)$ & $119,000( \pm 265)$ & $366( \pm 3)$ & 208,467 & 3 \\
\hline
\end{tabular}

${ }^{\mathrm{a}}$ Zone (Z) 2 to Z7: Lower Mt. Simon Formation; Z8 to Z9: Upper Mt. Simon Sandstone; Z10 to Z11: Ironton-Galesville Formation.

${ }^{\mathrm{b}}$ All physical values except temperature were measured at the wellhead after field parameters stabilized and do not represent in situ conditions. 
${ }^{\mathrm{c}}$ Standard deviations or standard errors for analytical analyses are in parentheses; $n=$ number of analyses for the analytes (for $n \geq 3$, standard deviation was applied; for $n \leq 3$, standard error was used in analyses).

${ }^{\mathrm{d}}$ Isotope activity or salt effect calculated following Horita et al. $(1993,1994): 10^{3} \ln \Gamma{ }^{18} \mathrm{O}=\Sigma\left[m_{i}\left(a_{i}+b_{i} / T\right)\right]$ where $m=$ molality, $T=$ temperature (K), $i$ is the $i$ th salt, and experimental parameters of $a_{i}\left(\right.$ molality $\left.^{-1}\right)$ and $b_{i}\left(\mathrm{~K} \times\right.$ molality $\left.{ }^{-1}\right)$ were determined for $\mathrm{NaCl}, \mathrm{KCl}, \mathrm{MgCl}_{2}, \mathrm{CaCl}_{2}, \mathrm{Na}_{2} \mathrm{SO}_{4}$, and $\mathrm{MgSO}_{4}$. These values were used to calculate the brine $\delta^{18} \mathrm{O}$ and $\delta \mathrm{D}$ activities.

${ }^{\mathrm{e}}$ Theoretical oxygen isotope equilibrium calculations using the equation from Zeebe (2010).

${ }_{\mathrm{f}}^{\mathrm{f}}$ Empirical oxygen isotope equilibrium calculations using the equation from Halas and Pluta (2000). 
Table 2

Sulfate isotope analysis of CAS and anhydrite samples from the Eau Claire and Bonneterre Formations

\begin{tabular}{|c|c|c|c|c|c|c|c|c|}
\hline Formation & Location & $\begin{array}{l}\text { Sample } \\
\text { ID }\end{array}$ & $\begin{array}{l}\text { Depth } \\
\text { (m) }\end{array}$ & $\begin{array}{c}\delta^{18} \mathrm{O}(\%) \\
\left(\mathrm{SO}_{4}\right) \\
(\mathrm{V}-\mathrm{SMOW})\end{array}$ & $\begin{array}{c}\delta^{34} \mathrm{~S}(\%) \\
\left(\mathrm{SO}_{4}\right) \\
(\mathrm{V}-\mathrm{CDT})\end{array}$ & $n$ & $\begin{array}{l}\text { Distance } \\
\text { from top of } \\
\text { formation } \\
\text { (m) }\end{array}$ & $\begin{array}{l}\text { Formation } \\
\text { thickness } \\
\text { (m) }\end{array}$ \\
\hline \multicolumn{9}{|l|}{$C A S$} \\
\hline Eau Claire & $\begin{array}{l}38^{\circ} 39.81^{\prime} \mathrm{N} \\
89^{\circ} 46.30^{\prime} \mathrm{W}\end{array}$ & C-8948 & $1,432.5$ & $1.4( \pm 0.24)$ & $21.3( \pm 0.01)$ & 2 & 0.5 & 136 \\
\hline Bonneterre & $\begin{array}{l}37^{\circ} 39.0^{\prime} \mathrm{N} \\
91^{\circ} 9.0^{\prime} \mathrm{W}\end{array}$ & $\begin{array}{l}\text { Buick } \\
\text { Mine }\end{array}$ & 335 & $0.1( \pm 0.42)$ & $14.7( \pm 0.04)$ & 2 & 3 & 93 \\
\hline Eau Claire & $\begin{array}{l}38^{\circ} 39.81^{\prime} \mathrm{N} \\
89^{\circ} 46.30^{\prime} \mathrm{W}\end{array}$ & C-8949 & 1,417 & $-1.5( \pm 0.11)$ & $11.2( \pm 0.00)$ & 2 & 27 & 91 \\
\hline Eau Claire & $\begin{array}{l}38^{\circ} 40.68^{\prime} \mathrm{N} \\
89^{\circ} 45.19^{\prime} \mathrm{W}\end{array}$ & C-8949 & 1,446 & $-2.6( \pm 0.06)$ & $9.3( \pm 0.09)$ & 2 & 56 & 91 \\
\hline Eau Claire & $\begin{array}{l}38^{\circ} 40.68^{\prime} \mathrm{N} \\
89^{\circ} 45.19^{\prime} \mathrm{W}\end{array}$ & C-8949 & 1,448 & $-2.1( \pm 0.18)$ & $10.6( \pm 0.06)$ & 2 & 58 & 91 \\
\hline \multicolumn{9}{|l|}{ Anhydrite } \\
\hline Eau Claire & $\begin{array}{l}39^{\circ} 50.1^{\prime} \mathrm{N} \\
89^{\circ} 51.5^{\prime} \mathrm{W}\end{array}$ & VW1 & 1,681 & NA & 14 & 1 & 152 & 152 \\
\hline Eau Claire & $\begin{array}{l}39^{\circ} 50.1^{\prime} \mathrm{N} \\
89^{\circ} 51.5^{\prime} \mathrm{W}\end{array}$ & VW1 & 1,681 & NA & 14 & 1 & 152 & 152 \\
\hline Eau Claire & $\begin{array}{l}38^{\circ} 36.0^{\prime} \mathrm{N} \\
89^{\circ} 07.8^{\prime} \mathrm{W}\end{array}$ & $\begin{array}{c}\text { TO } \\
52358 \# 2\end{array}$ & 2,366 & NA & 14 & 1 & 50 & 263 \\
\hline
\end{tabular}


Fig. 1

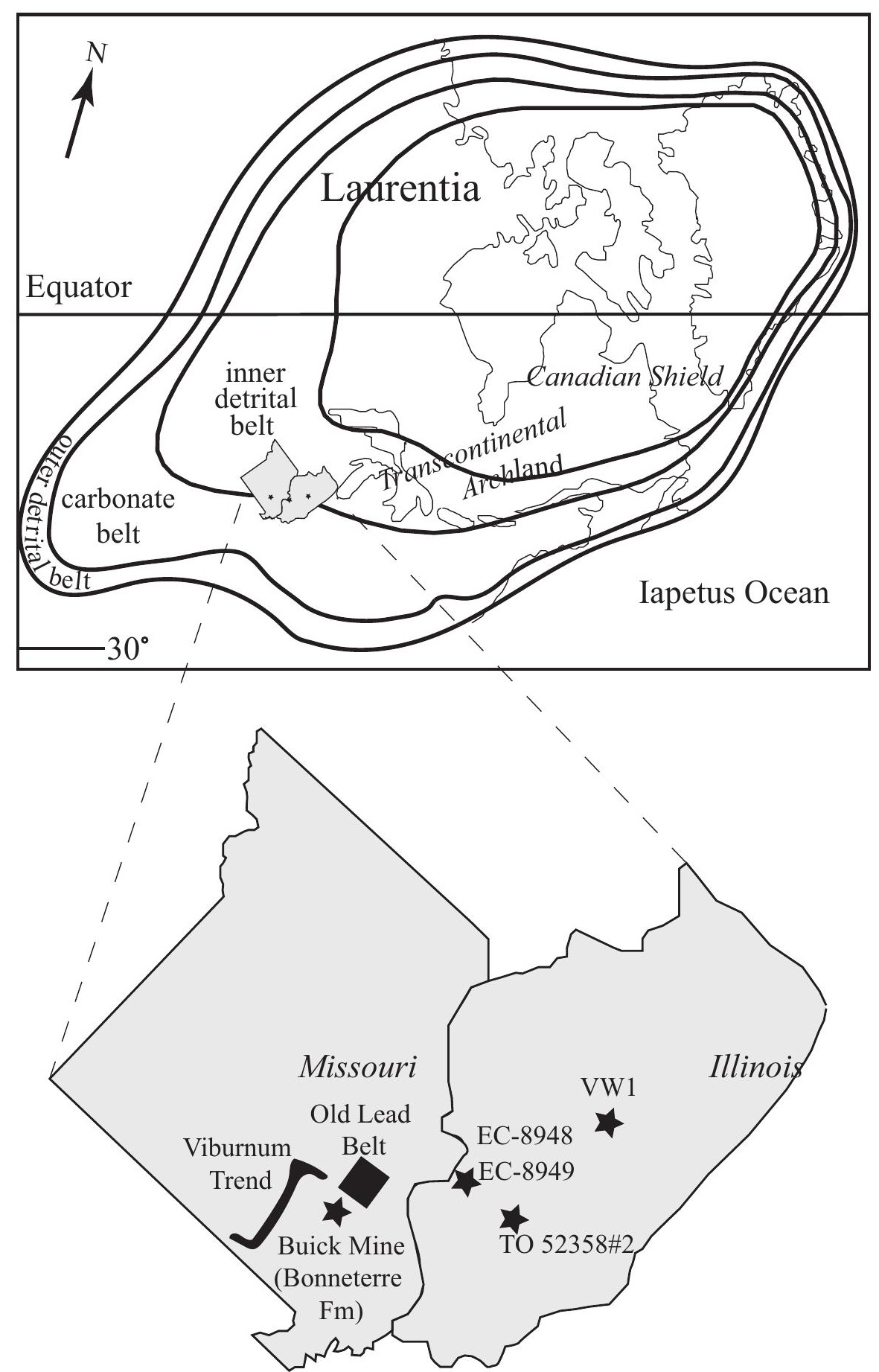


Fig. 2

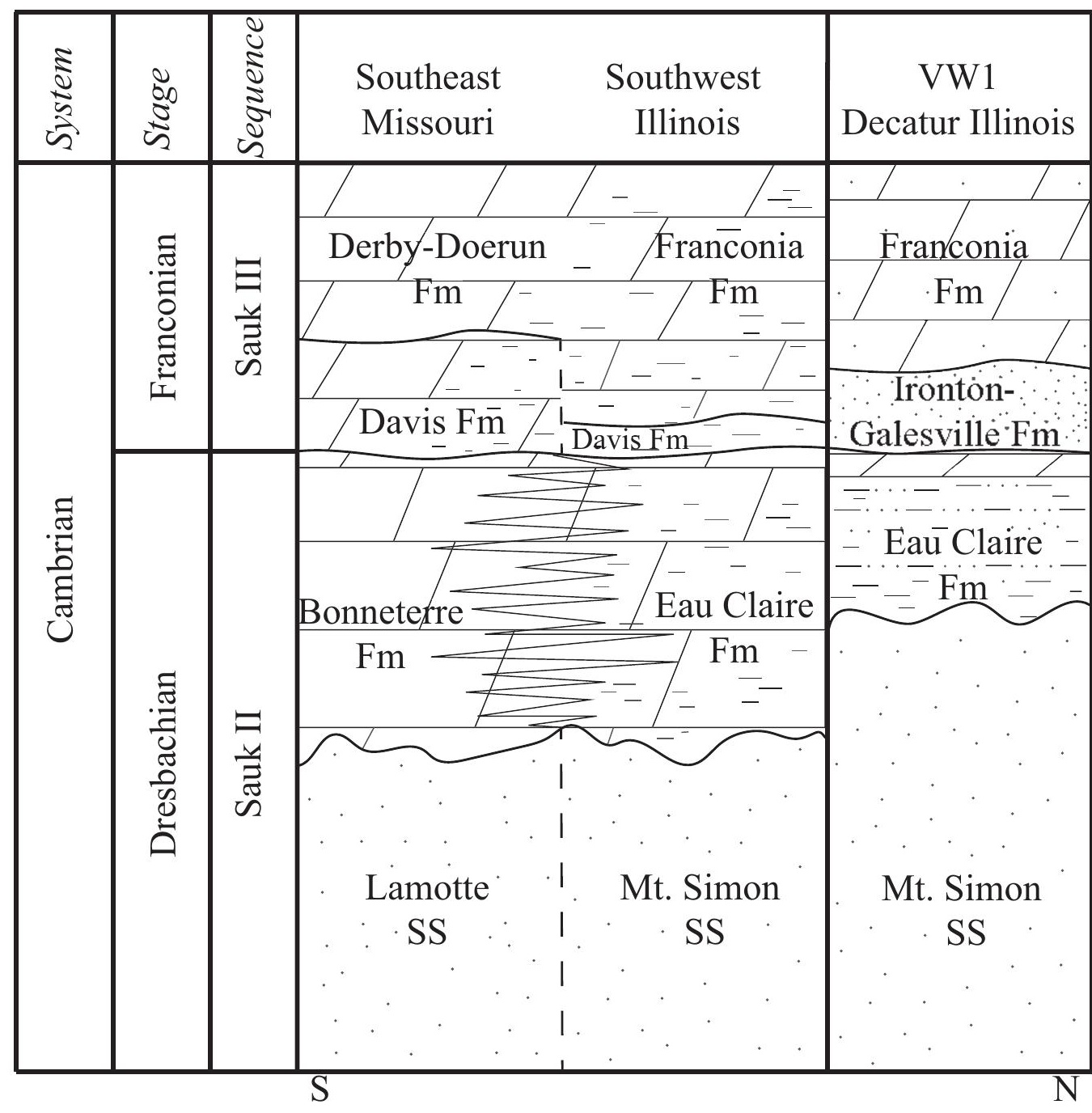


Fig 3

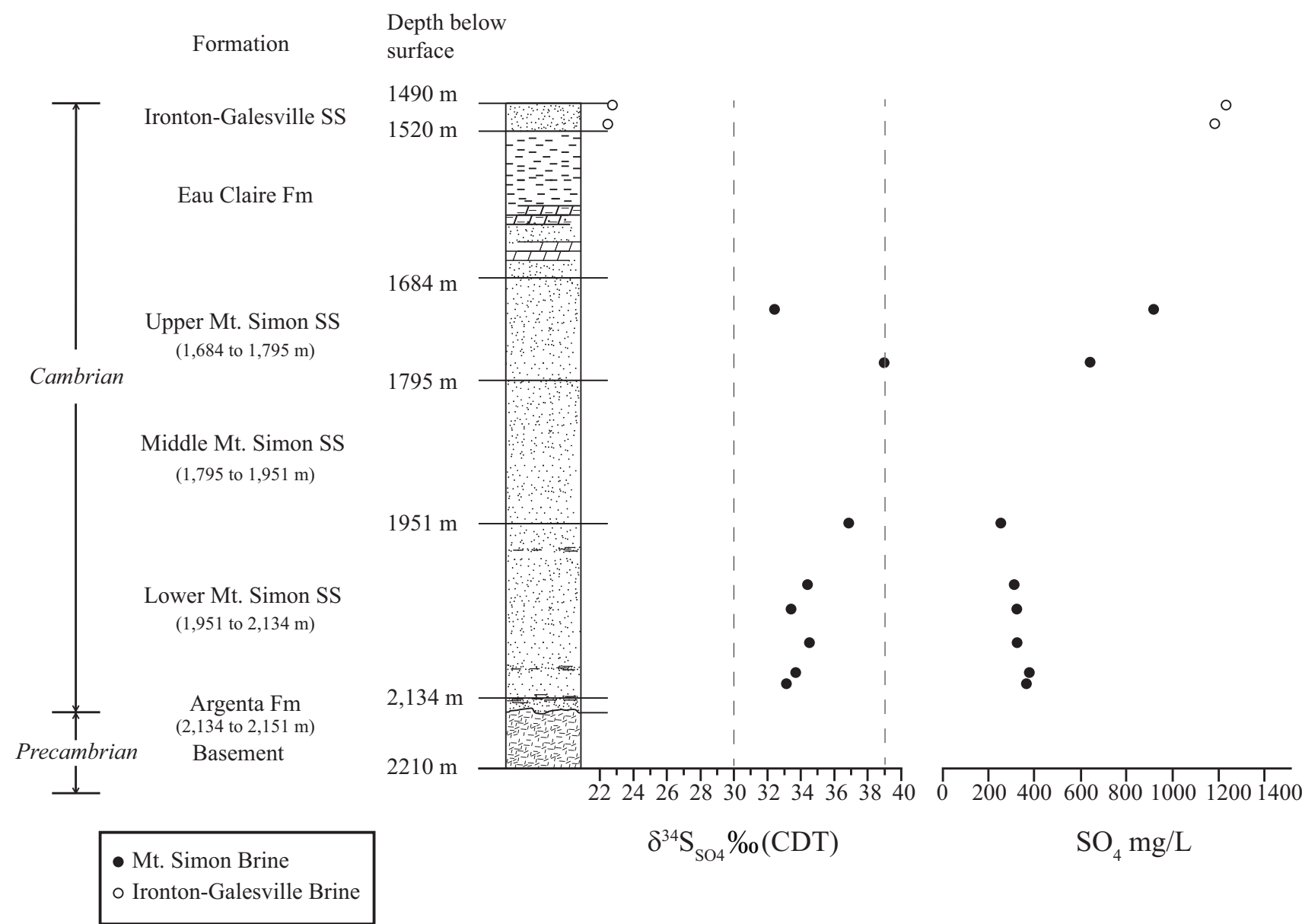


Fig 4

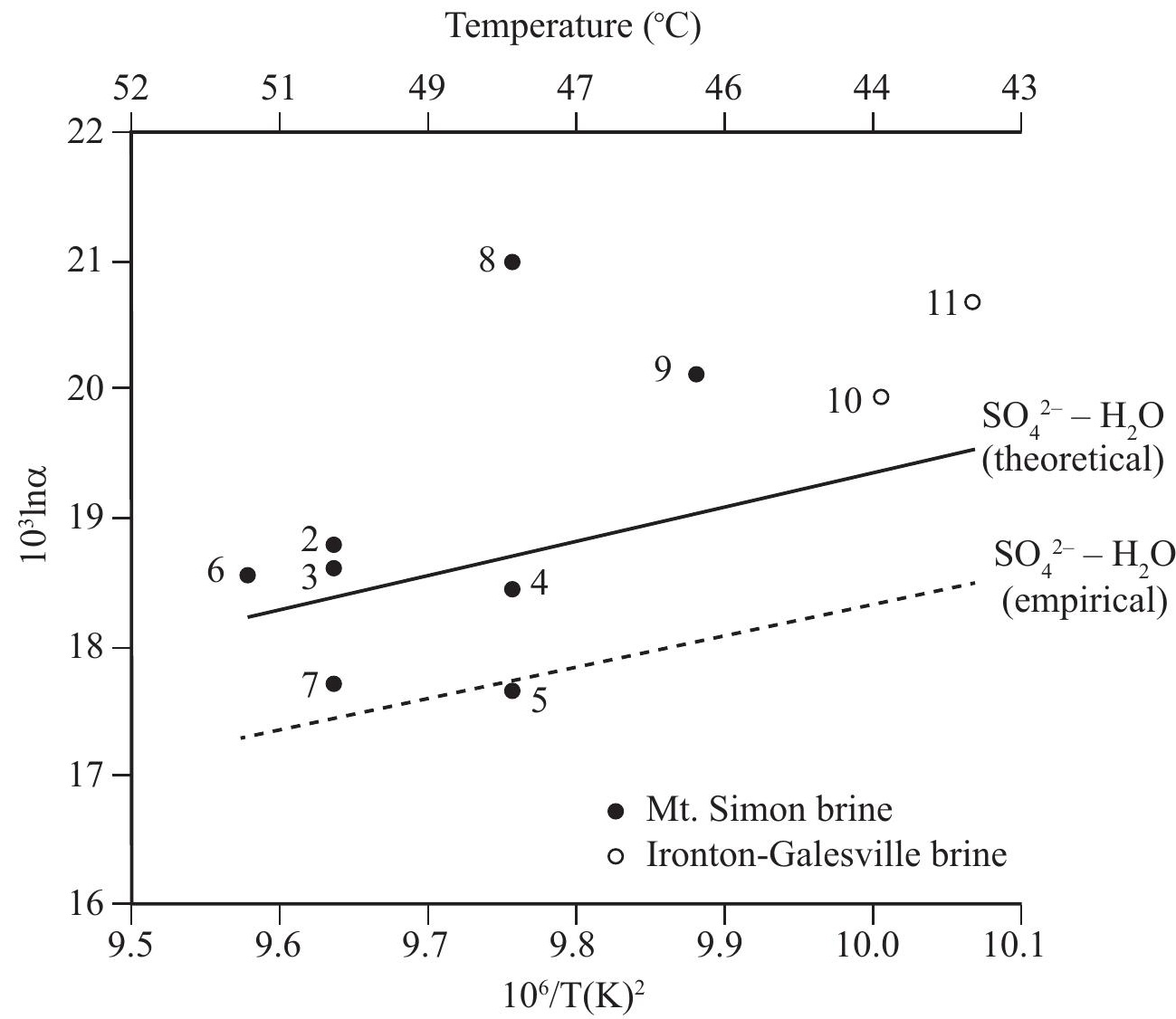


Fig 5

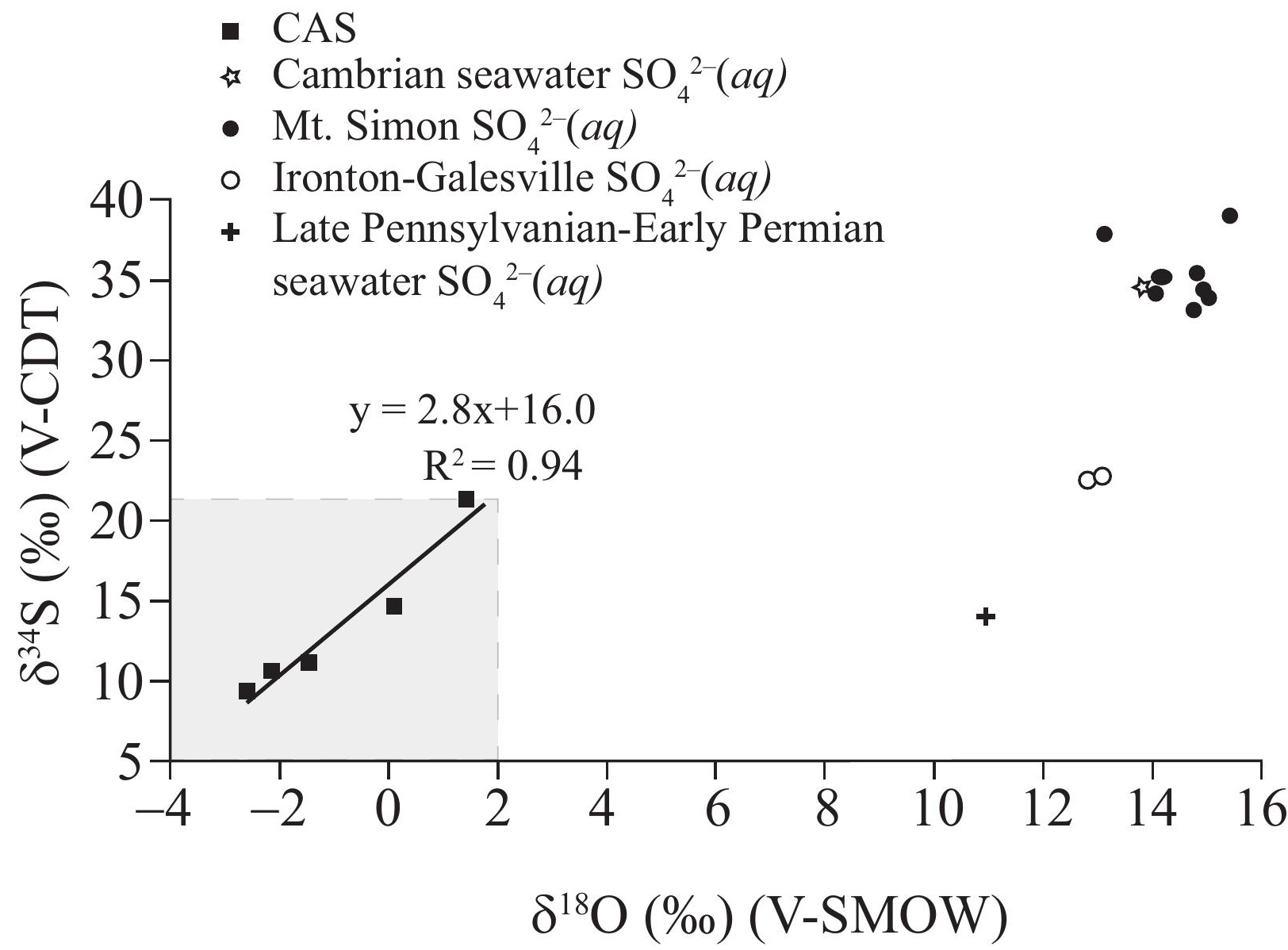

